\title{
AS DINÂMICAS FORMAIS/INFORMAIS E MODUS OPERANDI DA MOBILIDADE DA POPULAÇÃO FRONTEIRIÇA DO SUL DE ANGOLA
}

\author{
Sónia Cristina Cardoso dos Santos Silva \\ Universidade Katyavala Bwila Benguela, Angola \\ E-mail: soniac.silva@yahoo.com.br \\ ORCID: https://orcid.org/0000-0002-8126-8492
}

Data de recebimento: 20/04/2020

Data de aprovação: $21 / 10 / 2020$

DOI: https://doi.org/10.30612/frh.v22i40.13265

\begin{abstract}
Resumo: $\mathrm{O}$ artigo dedica-se à caracterização da mobilidade populacional na fronteira Sul de Angola (Angola/ Namíbia), nos três períodos históricos em análise - pré-colonial, colonial e pós-colonial. Com ou sem delimitações formais da linha fronteiriça, na região encontramos dinâmicas de mobilidade populacional, sobretudo entre as populações que habitam a zona. As dinâmicas de mobilidade caracterizam-se pela existência de mecanismos informais (dos dois lados da fronteira), a que se acrescentam mecanismos formais, adotados pelos Estados, de controlo dessas dinâmicas.
\end{abstract}

Palavras- chave: Fronteira, Mobilidade, Mecanismos Formais e Informais

\section{THE FORMAL /INFORMAL DYNAMICS AND THE MODUS OPERANDI OF THE BORDER POPULATION MOBILITY IN THE SOUTH OF ANGOLA}

\begin{abstract}
The current scientific paper describes the characterization of the population mobility in the South of Angola geographic boundary (Angola/Namibia), over the three historical periods under analysis - the pre-colonial, the colonial and the post-colonial. With or without formal delimitations of the geographic boundary marks, we find, in the region at stake, dynamics of population mobility, especially among people that reside in that region. Such dynamics are characterised by the existence of informal instruments (from both sides of the border) as well as formal mechanisms, adopted by the States in order to control such dynamics.
\end{abstract}

Keywords: Geographic Boundary, Mobility, Formal and Informal Mechanisms.

\section{LA DINÁMICA FORMAL / INFORMAL Y MODUS OPERANDI DE MOVILIDAD DE LA POBLACIÓN FRONTERIZA DEL SUR DE ANGOLA}

Resumen: El artículo está dedicado a la caracterización de la movilidad de la población en la frontera sur de Angola (Angola/Namibia), en los tres períodos históricos bajo análisis: precolonial, colonial y poscolonial. Con o sin delimitaciones formales de la línea fronteriza, en la región encontramos dinámicas de movilidad poblacional, especialmente entre las poblaciones que habitan la zona. Las dinámicas de movilidad se caracterizan por la existencia de mecanismos informales (a ambos lados de la frontera), a los que se suman mecanismos formales, adoptados por los Estados, para controlar estas dinámicas.

Palabras clave: frontera, movilidad, mecanismos formales e informales. 


\section{Considerações Gerais sobre a Mobilidade transfronteiriça em África}

As fronteiras africanas, refletem diferentes impactos consoante os períodos ou contextos históricos. Até à forte ocidentalização do pensamento político africano, as fronteiras representavam mais locais de encontro e partilha do que separações estanques, uma característica de pendor sociocultural ocidental (ROBERT, 2013). De acordo com Wolfgang Döpcke (1999), a noção de limites e/ou zonas fronteiriças, ou seja, de territorialidade, a noção de fronteira como uma linha não era desconhecida na África pré-colonial. Além de dividir as terras das famílias dentro de unidades políticas, delimitava também os limites de chefias e reinos, muitas vezes rigidamente.

Prevalecia no Continente uma espécie de "soberania graduada" que se exercia de forma “absoluta no centro do Estado e ficando mais fraca na periferia”, mas mesmo assim é possível afirmar que em África não havia terras sem dono. Döpcke (1999), é apologista de que a noção de fronteira não foi introduzida em África pela colonização. Mesmo na Europa, o conceito de fronteira como linha é de formação recente, em substituição da noção de fronteira como zona.

A esse propósito, Santos (1998), refere que,"“as grandes formações políticas da África central não correspondiam a um espaço territorial bem definido. Era o conjunto das populações tributárias - por vezes de várias etnias - que identificava um reino." (SANTOS, 1998,p.412).Para Ferreira (2009,p. 8), a delimitação fronteiriça dos novos países africanos, no século XX, dá-se num contexto em que "as populações ainda não haviam incorporado os espaços políticos criados pela Conferência de Berlim (...)", mas a luta anticolonial decorreu nos espaços criados pelos próprios colonizadores, validando-se tacitamente as fronteiras traçadas e as divisões instauradas no século XIX. No interior das fronteiras africanas sob tutela colonial, vigorava "um tipo de organização social do espaço, no qual o colonialismo interno [era] o operador central, e em que existem [existiam] diferentes formas de apropriação e uso do território, (...), colocadas variadas formas de (...), exploração do trabalho". Segundo Döpcke (1999), nos Estados africanos pré-coloniais e naqueles ainda não totalmente dominados pela colonização, a noção de fronteira era bastante variável, sendo notória a sua permeabilidade. Assim, mesmo não sendo ignoradas, as fronteiras eram permeáveis à mobilidade das populações, e a "força de identificação étnica além das fronteiras (...) integra o mapa mental e as identificações das pessoas."

Na ótica de Oliveira (2005), África não estava desprovida de estruturas institucionais, desenvolvidas em função de lógicas próprias e não necessariamente coincidentes com interesses 
das potências coloniais. Estas estruturas ajudam a compreender como as fronteiras traçadas na época colonial, e assumidas pelos novos Estados independentes, têm influência no modus vivendi das populações, com fortes laços consanguíneos, vivendo em ambos os lados das fronteiras, e como os respetivos governos gerem os recursos naturais e a mobilidade transfronteiriça das populações, considerando que as fronteiras políticas não coincidem necessariamente com as fronteiras étnico-culturais.

As fronteiras dos atuais Estados africanos - não obstante a criação de novas entidades resultantes da redefinição de anteriores fronteiras, casos da Eritreia e do Sudão do Sul - são, ainda, as mesmas 'herdadas' do período colonial e, mesmo que parcial e esporadicamente contestadas e disputadas, são mutuamente reconhecidas.Com percursos de certo modo diferentes, para Augustoni e Viana (2010), os processos de demarcação das fronteiras em África foram sempre conflituosos, levando populações consanguíneas a separarem-se em diferentes países. Esses processos, externamente impostos, modificaram o status quo de África.

Em Angola, onde a independência foi mais tardia, com um complicado processo de descolonização, também há casos de populações separadas (por exemplo, os Chokwes nas Lundas e Moxico, os Kwahamas no Cunene). Se essas fronteiras provocaram mudanças e exigiram adaptações, tanto das populações como dos Estados, não geraram, porém, conflitos graves.

Deste modo, o estabelecimento das fronteiras a Sul de Angola (Angola/Namíbia) - e, em termos gerais, em África - foi um processo resultante de interesses particulares na busca e exploração dos recursos naturais das regiões, bem como da implementação dos princípios ditados pela Conferência Internacional de Berlim quanto à partilha e ocupação efetiva de África. Foi um processo de prolongadas e conflituosas negociações entre potências europeias, intercaladas com acordos com alguns chefes africanos, com profundas implicações na mobilidade das populações que habitavam nas zonas fronteiriças. As populações foram obrigadas a transitar de sistemas políticos regidos por normas tradicionais/consuetudinárias para um regime orientado por filosofias económicas, jurídicas e organizativas estranhas ao seu tradicional, e então já consolidado, modo de vida. A partilha de espaços físicos, cuja natureza permitia mobilidade na gestão dos recursos naturais pelas populações e Estados, era uma destas consequências lógicas.

Entre os africanos, e os seus sistemas políticos, a noção de fronteira nem sempre foi coincidente com aquela que vigorava nos Estados europeus, e que foi transposta para os territórios ultramarinos. Sobrepunham-se questões que têm a ver com diferentes conceções 
filosóficas e sociológicas na construção política, administrativa e cultural dos diferentes povos. Os movimentos migratórios que caracterizaram África durante séculos - sobretudo as migrações bantu que deram origem a novas chefaturas e mesmo novos Estados - não permitem uma construção de paradigmas de fronteira ao mesmo nível de pensamento político dos europeus. A construção dos Estados africanos teve desenvolvimentos diferentes, e por isso permanecem diferentes visões quanto ao poder/soberania e o território, à transfronteiralidade do uso dos recursos, das relações entre Estados e da mobilidade das populações.

Döpcke (1999) refere que embora as linhas fronteiriças permaneçam na mente e na identificação dos povos, as fronteiras funcionavam, ainda na época colonial e nos tempos dos Estados africanos modernos, mais como zonas de contacto do que zonas de exclusão, pois a mobilidade das populações não foi totalmente abolida. Contra o argumento da artificialidade das fronteiras africanas e das barreiras à movimentação das populações, o mesmo autor sustenta que as barreiras naturais não representam fronteiras no espaço cultural, político ou económico criado pelas sociedades humanas mas, pelo contrário, muitas vezes, vias de comunicação e interligação.

A compreensão do fenómeno da "mobilidade populacional", recorrente em toda a África, implica que se tenha em conta que, no caso do nosso estudo, a unidade de análise mais próxima das fronteiras é o domicílio rural (BARBIERI, 2007). Foi possível constatar que as populações rurais movem-se frequentemente para o interior dos dois países, onde facilmente são absorvidas. A dimensão temporal desta mobilidade revela-se importante, porque em função do tempo de permanência realizam- se atividades produtivas, implicando o uso da terra com incidência sobre o meio ambiente.

Na perspetiva de Amaral (1997, p.3), abordando as consequências do estabelecimento das fronteiras para a mobilidade populacional nas várias regiões, a forma como foram estabelecidas as fronteiras em África teve múltiplos efeitos: as economias fracassaram e os africanos perderam a mobilidade política e social que tinham no interior do continente. As várias economias já integradas - antes do século XV - reduziram-se a espaços consumidores do que vinha do estrangeiro. Em poucos anos alguns países viram as suas fronteiras (limites) marítimas estreitadas, com o território estendido para o interior, como se verifica na configuração geográfica, por exemplo, no Sudão, Congo, Guiné-Conacri, Nigéria e Camarões.

Por outro lado, Döpcke (1999) defende que estas barreiras artificiais não são suficientes para impedir contactos transfronteiriços, quanto mais não seja porque muitas estão insuficientemente policiadas ou não têm uma linha de demarcação clara. Analisando a fronteira 
entre Moçambique, o Malawi e a Zâmbia, Döpcke (1999) aponta para a apropriação da fronteira pelas populações, nomeadamente os Chewa e os Ngoni, presentes nos territórios dos três países: os zambianos atravessavam a fronteira com Moçambique para ali cultivarem, entretanto deixavam os seus filhos em casa para que estes frequentassem a escola, que pensavam ser melhor que as de Moçambique; os moçambicanos, por seu turno, também mandavam os seus filhos para frequentarem as escolas na Zâmbia. Este triângulo fronteiriço mostra a integração de povos artificialmente separados.

A mobilidade populacional e a travessia da fronteira, segundo Döpcke (1999: 97), incluem a fuga da repressão racial no sentido de uma melhor mobilização e organização da luta armada contra os regimes coloniais e racistas na África Austral, "caso de Angola, Moçambique, Zimbabué, Namíbia e África do Sul”. Nos dias de hoje, as fronteiras representam uma quase que única hipótese de sobrevivência das populações em face das guerras civis nos seus países. Em 1995, cerca de sete milhões de pessoas atravessaram fronteiras internacionais, procurando refúgio em países vizinhos. (DÖPCKE, 1999, p. 97)

Todos os argumentos apontados por Döpcke (1999,p. 95) servem para demonstrar que as fronteiras modernas na África não representam, nem na época colonial nem na atualidade, barreiras efetivas para o movimento da população. Eram e são permeáveis, são mais zonas de contacto do que de exclusão. Não deixam por isso de estar presentes na mente e na identidade dos povos. As fronteiras representam uma realidade na vida das pessoas. Elas são apropriadas, utilizadas e, no seu significado, permanentemente renegociadas, em vez de simplesmente ignoradas.

Para uma melhor compreensão dos factos históricos, é preciso primeiramente estudar os deslocamentos normais, ordinários, ligados à busca dos meios de subsistência, no sentido de compreender melhor, por oposição, os deslocamentos inabituais, anormais. Assim se pode perceber como se produzem, em concreto, os diferentes movimentos populacionais. (OGOT, 2010).Em África, os meios de sobrevivência, em função do meio, dependem essencialmente de quatro atividades: a caça associada à colheita, a criação de gado e animais domésticos, o cultivo do solo e a pesca (LAMPHEAR, 1976, apud OGOT, 2010: 59).Em África os deslocamentos variam também em função das estações. Os deslocamentos sazonais ocorrem nas zonas florestais na época da coleta do mel ou ainda nos arredores do deserto de Kalahari, na época da frutificação ou quando os mamíferos se aproximam ou se afastam das fontes de água. Não obstante a sua grande mobilidade, tais grupos podem explorar os mesmos territórios durante muito tempo, sendo que os criadores de gado também se deslocam. Por outro lado, os animais 
dos quais eles tiram sua subsistência têm necessidade de água, de pastagem e de sal. E aqui enquadramos a necessidade de migrações transfronteiriças entre Angola e Namíbia em busca de cacimbas, poços de água e bom pasto entre outros. (LAMPHEAR, 1976 apud OGOT, 2010, p. 59)

A compreensão da perspetiva etno-histórica da região passa pela abordagem transfronteiriça de Bollig e Gewald (2009: 271) que argumentam que "o himba do noroeste da Namíbia (província do Cunene) e o sudoeste de Angola (província do Cunene e província do Namibe) pertencem a um grupo de povos de pastores e pastores agropecuários de fala Bantu". Refere-se, portanto, a um mesmo grupo a povoar dois Estados soberanos, separados por uma fronteira política. Tal faz com que encontremos nos dois países similaridades nas atividades económicas, assentes na pastorícia, e uma mesma identidade cultural, cuja língua constitui o referencial imediato de que ambos os povos descendem de um tronco comum. Segundo Bollig e Gewald (2009: 272), "são basicamente dialetos de otjiherero que é falado principalmente em Namíbia central" e constituem "línguas [...] bastante relacionadas com outros dialetos do grupo Bantu sudoeste" de Angola, a que se juntam, no município do Coroca, povos de etnia muhimba.

Trata-se de um conjunto de características da vida doméstica e da atividade económica, partilhado por populações que vivem ao longo das linhas de fronteira do Sul de Angola e Norte da Namíbia. O cultivo, com alguma intensidade, do milho, do massango, da massambala e criação de gado, essencialmente bovino, são a base da economia, complementada pelo pequeno comércio transfronteiriço. Sendo assim, a alimentação baseia-se em carnes, cereais com leite de vaca misturado com ondjove (uma espécie de manteiga preparada de modo tradicional e ancestral).

Quanto à habitação, as casas são feitas de pau-a-pique (troncos finos de árvores servindo de paredes recobertas, quase sempre de barro, e cobertas de capim), de modo semelhante em ambos os lados da fronteira. Os núcleos familiares vivem distanciados uns dos outros entre dois e três quilómetros.

\section{População de Angola}

A população angolana é na sua maioria de origem Bantu, excetuando-se os Vátua ${ }^{1}$, os Kuroca, os Koi-san que, de acordo com alguns estudos, são os autóctones de facto ou pré-Bantu

\footnotetext{
${ }^{1}$ Os Vátua, ou Curocas, são autóctones ou pré-bantu segundo Zau (2010, p. 1-2) estabelecendo-se na região que cruza o rio Curoca e o território adjacente, localizando-se "entre o deserto do Namíbe e a Serra da Chela". Pelo
} 
do território. A história do povoamento de Angola perde-se no tempo, devido às referências aos pré-Bantu que foram sendo "empurrados" para Sul, à medida que os Bantu entravam e ocupavam os seus espaços até à constituição dos seus reinos e principados. Entre os Vátua encontra-se os subgrupos Cuepes ou Vacuissis (pejorativamente) que se designam a si próprios por "ova-mbundia" e "va-kwando" (WHEELER e PÉLISSIER, 2013). Estes autores consideram que os Bantu que conformam o tecido etnolinguístico do território de Angola constituem oito grupos diversificados e distintos, mas que conservam traços comuns, designadamente: (i) os Bacongo a Noroeste, incluindo o enclave de Cabinda; (ii) os Kimbundu no baixo vale do Cuanza, entre as margens do médio ao baixo Cuanza; (iii) os Ovimbundu no Planalto Central (tidos até ao censo de 1970 como sendo o grupo étnico mais numeroso da colónia); (iv) os Lunda-Kioco a Nordeste; (v) os Nganguela, dividindo espaços entre os Ovimbundu e os Lunda-Kioco; (vi) Nyaneka-Nkhumbi; (vii) Herero; (viii) Ovambo. (ZAU 2010, p. 1-2)

Para Silva (2003), os povos de Angola são tradicionalmente agropastoris, criando sobretudo gado bovino, sendo: 32\% Ovimbundu, 46\% Nyaneka-Nkhumbi ou Nyaneka-Humbe, 13\% Ovambo. O último grupo integra os Cuanhama, que constitui o grupo representativo do presente estudo. Monteiro (1994: 12), conclui que "numa visão global do mosaico étnico de Angola, (...) seis dos nove grupos étnicos (Ovimbundo, Ambundo, Congo, Lunda-Quioco, Ganguela e Nhaneca-Humbe para além de ocuparem enormes extensões territoriais, subdividem-se em elevado número de subgrupos, alguns deles superiores a duas dezenas". Segundo o mesmo autor, na parte Sul de Angola sobressaem três grupos étnicos - Ambó, Herero, Xindonga - ocupando um território não demasiado amplo.

Toda a nossa investigação se centra no povo Ambó (com ênfase para o maior grupo, os Cuanhamas) que terá particular destaque tanto pela sua localização geográfica na área da fronteira, como por se tratar "de um povo com particularidades distintas da maioria das etnias angolanas, incluindo dos seus próprios vizinhos" (MONTEIRO, 1994: 12). Abrange, contudo, o conjunto de outros povos e pessoas de origem diversificada que se fixaram na região ao longo dos tempos e que, independentemente da sua origem "étnica" participam da vida quotidiana e das dinâmicas locais transfronteiriças.

\footnotetext{
facto de não praticarem a metalurgia e a cerâmica, o autor considerou-os como estando num estádio de desenvolvimento bastante primário. Vivem da criação de gado e da agricultura de subsistência. Os Vátua integram os subgrupos Cuissis e Cuepes. É na interação com os Bantu, como Ovambo, Herero e Ovimbundu que introduzem na sua cultura a indústria do ferro, no início da década de 30 do século passado.
} 
As dinâmicas formais/informais e modus operandi da mobilidade da população fronteiriça do sul de Angola Sónia Cristina Cardoso dos Santos Silva

O Kwanhama ${ }^{2}$, cujo antigo reino ocupou uma vasta área em Angola e Namíbia, constitui um dos exemplos em África de povos divididas pelo estabelecimento de fronteiras coloniais. Os Cuanhamas (KWANYAMA ou OXIKWANYAMA) ocupam um vasto território que vai desde as proximidades da Vila de Roçadas, seguindo a margem esquerda até Ruacaná, confinando com savanas semi-desérticas, território dos Himbas, até a foz do rio Cunene no Namibe (Oceano Atlântico), transpondo a fronteira angolana, e penetrando na actual Ovambulândia, Namíbia. Os Cuanhama pertencem ao grande grupo étnico dos Ovambo, que na literatura etnográfica portuguesa são conhecidos como Ambós, como referido. O grande grupo Ovambo inclui 12 subgrupos espalhados em ambos os países. Linguisticamente estão divididos em Oshikwanhama e Ondonga. No início do século XX, são encontrados cinco subgrupos Ambós: Kwanhama (76,7\%), Cuamato (15,7\%), Evale (6,8\%), Cafima (0,7\%) e Dombon (0,1\%). (Neto, 1963:16 apud Udelsmann Rodrigues, 2017: 6). Antes da independência de Angola, havia cerca de 120 mil Ovambo em Angola e cerca de 415 mil na Namíbia. Na atualidade, os Cuanhamas partilham o espaço com outros povos, como os Cuamatos e Muvales, Nyanecas, Humbes e Hereros. Contudo, a língua que predomina nesta região é o Cuanhama

No seio deste grande grupo, a atividade piscatória era feita em grupo por homens e mulheres, sobretudo em anos em que se verificavam grandes cheias, ao longo de rios como o Cuvelai (Mupa e Evale), áreas com maior abundância de peixe. Já a caça era uma atividade de relevo, uma vez que refletiu o "primeiro estádio da sua evolução económica, designadamente entre os Ova-Kwa-nyama (os da carne)", que supostamente pela grande quantidade existente, se tinham fixado nesta região. Todavia, com o decurso do tempo, a caça passou para segundo plano, mesmo que no período de transumâncias esteja bastante presente na dieta alimentar (MONTEIRO, 1994: 204). O gado tinha não só valorização económica como social, o que fazia com que a sua comercialização fosse fenómeno bastante complexo, mesmo alvo de uma certa relutância (MONTEIRO, 1994). Atualmente, continua a ter grande significância económica e social, mantendo-se igualmente no centro das dinâmicas relativas ao acesso e gestão aos recursos naturais, sobretudo a terra/pasto e à água.

\footnotetext{
${ }^{2}$ Segundo a investigação efetuada por Udelsmann Rodrigues (2007: 18), exposta no seu artigo que aborda a identidade Kwanhama, no idioma original o plural correto escrito em português é Ovakwanhama. Porém, a literatura colonial de Angola introduziu o plural Kwanhamas, baseado no português. Este termo é de uso comum e ao longo do texto poderá encontrá-lo grafado Kwanhama ou Cuanhama, conforme o autor consultado. As grafias Cuanhama e Ovakwanyama são normalmente encontradas em textos e referências publicadas em Inglês. De referir que a grafia nacional angolana, desde meados de 2018 , voltou a adotar o C inicial, em detrimento do $\mathrm{K}$. Nas nossas abordagens usaremos "C", mas optamos por respeitar a grafia de cada autor, particularmente em caso de citação.
} 


\section{Mandume Ndemufayo, rei dos Cuanhamas}

O rei Mandume Ndemufayo ${ }^{3}$ foi o último chefe dos Cuanhamas independentes e lutou contra a presença e ocupação portuguesa (Aparício, 2000: 226). Com efeito, as populações do sul de Angola e do norte da Namíbia, integrantes da "nação ovambo" reveem-se num herói comum, o rei Mandume, que combateu os portugueses e estabeleceu alianças estratégicas com os alemães.

Mandume, diplomata hábil e exímio estratega, dirigiu os destinos deste povo desde muito jovem, tendo perecido em 1917 no território neutro. Lutando contra a presença de portugueses e alemães, considerava os portugueses mais fraternos. Tirando partido das rivalidades étnicas, projetou a criação de uma liga ovambo, para expulsar o inimigo comum. Machado (1927) afirma que antes da instalação das missões, os sobas mantinham uma boa relação com os portugueses, citando nomes como Eyuolo e Nandi, tendo permitido o desenvolvimento do comércio com a abertura de estabelecimentos comerciais em Ondjiva. Entretanto com a morte destes “aliados" dos portugueses e a ascensão de Mandume, as relações sofrem algumas alterações. O confronto decisivo deu-se junto às cacimbas de Môngua. Os portugueses, apesar de terem perdido muita munição e com pouca mobilidade, ocupam as cacimbas, criando trincheiras para "o controlo da água [...] extremamente importante naquela região", pois determinava quase que o seu vencedor (Aparício, 2000: 227).

Segundo Udelsmann Rodrigues (2017: 2), a identidade transfronteiriça concentrou-se progressivamente na ideia de uma divisão entre os dois países, assente na figura de Mandume, rei dos Kwanhama, que, tendo perecido em 1917, se crê ter sido "enterrado em ambos os lados da fronteira", o corpo do lado angolano e a cabeça do lado namibiano ${ }^{4}$. Estamos perante uma noção de pertença comum, para lá da fronteira. Esta divisão do rei é vista como "símbolo da identidade transfronteiriça de Kwanhama", marcada pelas "transformações sociopolíticas das últimas décadas em ambos os países", desde 1975 e 1989/1990, datas que marcam a independência de Angola e o processo de independência da Namíbia, respetivamente.

Na ótica de Udelsmann Rodrigues (2017), a imposição da fronteira e vários outros processos históricos determinaram “a construção da identidade Kwanhama”. Esta identidade

\footnotetext{
${ }^{3}$ Mandume Ndemufayo reinou entre 1911 e 1917. Figura polémica, considerado cruel na governação do seu povo, porém venerado até hoje, quer pelos Cuanhamas quer pelos grupos Ovambo.

${ }^{4}$ Segundo reza a história, o rei Mandume morreu em território português, perseguido pelas tropas que depois extorquiram oito mil bois que lhe pertenceriam. Segundo Maia (1941) há dúvidas relativamente a relatos de que a sua cabeça fora enterrada juntamente com seu corpo em Namacunde.
} 
As dinâmicas formais/informais e modus operandi da mobilidade da população fronteiriça do sul de Angola Sónia Cristina Cardoso dos Santos Silva

comum foi incorporada dos dois lados da fronteira e naturalmente determinou a relação entre as populações dos dois Estados, tanto no que concerne à gestão da fronteira como à mobilidade populacional e dos recursos como a água, a terra e o gado.

A representatividade de Mandume como entidade comum ou transfronteiriça dos Kwanhama ganhou impulso com a construção, logo após o fim da guerra, em 2002, de um memorial em sua honra em Oihole, no Cunene. O memorial é uma atração turística procurada pelas populações dos dois países. Está prevista a instalação de uma estátua de $5 \times 4$ metros do monarca, encomendada pelo Governo, que deverá ser brevemente colocada na praça central da capital da província, Ondjiva (Udelsmann Rodrigues, 2017

\section{A província ao sul de Angola - o Cunene e sua Caraterização.}

De acordo com o Plano de Urbanização da Cidade de Ondjiva, a região apresenta uma constituição geológica particular, estando inserida na denominada Bacia de Sedimentação do Cuanhama-Etocha, do quaternário, e segmento estrutural da vasta Bacia do Kalahari. Constitui parte integrante da subunidade geormorfológica denominada por Marques (1977) como Depressão Endorreica do Cuvelai-Lueque"5 (República de Angola, Governo do Cunene, 2005: 24).

Segundo o programa de desenvolvimento da Província do Cunene:

A província situa-se na zona dos pastos doces, que mantém a adaptabilidade durante todo o ano e se localizam em zonas de baixa altitude e pluviosidade, bem como se encontram em formação de pastos acres, localizados em zonas de altitude superior a mil metros, e outras consideradas de pastos mistos, de altitudes médias e pluviosidade compreendida entre 750 e 1000 milímetros (PDPC, 2014: 21).

Apesar de a área do Cuamato beneficiar da existência de chanas, "estas não dão lugar à formação de camadas aquíferas, em virtude de as areias superficiais apresentarem uma certa consolidação e consequentemente maior impermeabilidade" (Monteiro, 994: 52-53). As chuvas são de pequena duração, pelo que a retenção não atinge os níveis desejáveis, mas mesmo assim

\footnotetext{
5 "Região residual da aplanação do Terciário médio, recoberta por espessos depósitos arenosos eólico-fluviais. Os materiais litológicos que compõem esta bacia de sedimentação são diversos, sendo a sua constituição mineralógica essencialmente representada por areia e argilas que se estruturam numa sequência estratigráfica de origem fluvial, definindo depósitos continentais do andar superior do Sistema do Kalahari. São também comuns arenitos ferruginosos, silicificados e calcários recobertos por areias de origem eólica, incluindo areias do Kalahari redistribuídas." Cf. República de Angola, Governo do Cunene, Plano de Urbanização da Cidade de Ondjiva, 2005, Volume I, p.24.
} 
o armazenamento desta água é de extrema importância para populações que se dedicam à pastorícia, aspeto intrinsecamente ligado às características hidrogeológicas dos solos da região (idem: 45). Todavia, "não obstante o relevo conferido à pastorícia toda população se dedicava a agricultura" (Monteiro, 1994: 153).

De acordo com Sanches (1999: 59) as características geomorfológicas dos territórios do Sul de Angola são propícias para a criação de gado de várias espécies, especialmente o gado bovino, registando-se esforços de diversificar as atividades económicas, com o objetivo de produzir riqueza que se reflita em bem-estar "para as populações predominantemente nómadas, vivendo em povoamentos dispersos".

Enquanto os Ovambo habitam nas planícies secas a Leste do Cunene, os Hereros habitam em planícies áridas e circulam entre a Namíbia e Angola, vivendo essencialmente da criação de gado bovino, o seu principal recurso. A intensa transumância implica um quase nomadismo, uma prática que ultrapassa a noção de fronteira territorial.

Economicamente, a agricultura rudimentar de hortícolas e de cereais, bem como a criação de gado, sobretudo bovino, são as principais atividades produtivas. A atividade agrícola é essencialmente de sequeiro, sendo que a irrigação se desenvolve quer na parte namibiana quer na parte angolana, essencialmente nas margens do rio Cunene. (Governo Provincial do Cunene, 2014). Os municípios do Curoca, de Ombadja e de Namacunde são localidades situadas na fronteira internacional. Pequenos produtores familiares e criadores de gado tradicionais dependem das chuvas para a sua atividade sendo ainda pouco significativa a existência de infraestruturas para a reserva de água, visando compensar os prolongados períodos de seca, de acordo com o Plano de desenvolvimento da Província do Cunene (PDPC, 2014).

A agricultura empresarial é de pouca expressão, progredindo lentamente nos municípios de Ombadja, Cuvelai e Cahama. As espécies agrícolas adotadas são as mais resistentes à carência de água, essencialmente entre os municípios de Ombanja e do Cuvelai. A produção de massango é a mais representativa pelas suas características de resistência à irregularidades das chuvas, mesmo sendo solos arenosos e pobres em águas superficiais (PDPC, 2014).

A pecuária é a principal fonte de subsistência da população, sendo não só um fator económico como social e mesmo de organização política, pelo menos simbolicamente. Sendo os sobas criadores de gado por excelência, a dimensão dos rebanhos tem não só uma importante dimensão económica como simboliza o seu poder dentro das comunidades. O gado bovino (e também algum caprino) é uma forma de poupança, uma alternativa a depósitos bancários, motivo pelo qual, mesmo diante dos constrangimentos provocados pelos prolongados períodos 
de estiagem, é muito raro que as famílias abatam cabeças de gado para consumo próprio. Excecionalmente, a venda de gado é um recurso para que os agregados familiares consigam alguma liquidez financeira. Estes aspetos são relevantes e constituem argumento para a nossa investigação, pois reforçam a necessidade de mobilidade de pessoas e gado através da fronteira.

No conjunto dos recursos naturais que abundam, essencialmente nos municípios do Cuvelai e Curoca, além da água, estão por explorar de forma economicamente rentável, o ferro, os diamantes e os granitos (vermelho e preto). Ao nível dos recursos florestais, a região tem espécies de onde se pode extrair madeira de qualidade, para utilização na construção civil e em mobiliário. Cuvelai, Namacunde e Cuanhama são os municípios onde há um maior aproveitamento destes recursos, como menciona o relatório A geopolítica da província do Cunene, de 2014, documento elaborado pela Polícia de Guarda Fronteiras do Cunene.

A província prospera atualmente graças à sua posição na principal rota comercial entre a Namíbia e Angola, com ligação à África do Sul pela estrada internacional ${ }^{6}$. A atividade comercial, a cobrança de taxas aduaneiras e de impostos são bastante intensas, impulsionadas pela proximidade com a República da Namíbia, de onde provêm, ou transitam, vindos da África do Sul, produtos - vendidos a preços mais competitivos que os praticados em outros pontos do país - altamente consumidos em Angola. Efetivamente, a cidade capital do Cunene, Ongiva, vive sobretudo dos serviços do comércio. Bastante atingida pela guerra, a cidade tem registado um crescimento assinalável desde 2002 (G.P. CUNENE, 2014).

Segundo A. Keese (2015:245), a história dos movimentos populacionais que atravessavam a fronteira entre o território português e o mandato sul-africano mostra a existência de um equilíbrio desigual entre os dois, mas com as autoridades portuguesas quase constantemente do lado dos vencidos. Esta observação permanece válida por um período de tempo considerável, entre 1915 e o final dos anos 1940. No entanto, as condições na região fronteiriça entre Ovamboland e o distrito de Cunene passaram por mudanças consideráveis no início dos anos cinquenta, com efeitos mais concretos e visíveis a partir de 1953. A partir deste ano, a migração do lado angolano foi transformada: de uma opção de saída para os relativamente poucos habitantes locais, desesperados o suficiente pelas condições fiscais e laborais problemáticas, transformou-se numa verdadeira alternativa. Para o mesmo autor (2015: 249), o aumento da migração dos Ovambos para Angola, nos anos finais do Estado colonial português, demonstra a relativa melhoria das condições sociais deste último. Em primeiro lugar,

\footnotetext{
${ }^{6} \mathrm{O}$ Cunene tem dois aeroportos, um em Ondjiva e outro na Cahama, bem como aeródromos em Xangongo,
} Namacunde e Curoca. 
o aumento lento mas constante dos salários (com uma diferença salarial que tinha diminuído no início dos anos 1960) e a eliminação de alguns dos piores abusos por parte dos empregadores europeus e da administração (nomeadamente através da eliminação progressiva do trabalho forçado entre 1950 e 1962), fizeram do trabalho em Angola uma verdadeira alternativa, mesmo para os imigrantes. Em segundo lugar, a atitude hostil que muitos administradores portugueses tinham tido em relação aos "assuntos nativos tradicionais" tornou Angola atraente como um refúgio para os indivíduos mais jovens, uma vez que a sua "fuga" para Angola os libertou do controlo dos mais velhos. Em suma, nas últimas fases do domínio português, entre o início dos anos 1950 e 1974, Angola tornou-se uma opção para algumas das pessoas do território do mandato sul-africano, uma vez que os salários já não eram significativamente mais baixos, as condições de trabalho tinham melhorado substancialmente, as ocupações estavam disponíveis para além do tão odiado trabalho nas minas, e os locais tinham a oportunidade de escapar às realidades sociais opressivas em casa, onde isso era aplicável (KEESE, 2015: 249)

As autoridades coloniais portuguesas não iniciaram um processo de melhoria da vida local através de um plano pré-fabricado. Embora este tenha sido, em parte, o caso nas regiões centrais da vida económica em Angola e, obviamente, nas regiões alvo da colonização branca após 1945, a região do Cunene não se tornou uma prioridade para as políticas sociais e económicas. A melhoria de condições na região foi parcialmente acidental. Mesmo assim, foi uma consequência de novas pressões, incluindo pressões morais, depois da Segunda Guerra Mundial. Um número crescente de administradores intermédios portugueses, particularmente membros da inspeção colonial em Lisboa, tinha-se convencido de que a repressão e a exploração tinham ido longe demais nos anos da guerra, e defendeu uma prática colonial mais benevolente. Portanto, dependendo da região, o trabalho forçado e a tributação excessiva foram lentamente moderados. A mudança dos padrões migratórios na região do Cunene até 1953 constitui uma evidência clara da melhoria da qualidade de vida da população do lado português da fronteira (KEESE, 2015: 253).

Em 1974, as condições sociais na região melhoraram consideravelmente, e o potencial para mais medidas era considerável, embora, mesmo pouco antes da Revolução dos Cravos, os planificadores portugueses em Angola e nas outras colónias não terem sido, naturalmente, capazes de considerar qualquer coisa como o empoderamento democrático das populações no Cunene. Mesmo assim, no que diz respeito às condições socioeconómicas da região, foi a guerra civil angolana, depois de 1974, que impeliu a região para uma espiral de violência e de subdesenvolvimento. Só depois do ano 2000 é que as condições voltaram a melhorar, graças ao 
apelo de uma fronteira colonial que, depois da vitória do MPLA no país, viria novamente a ser uma fonte de oportunidades (KEESE, 2015: 253).

Pode-se concluir que o "volume de correntes migratórias para o antigo Sudoeste Africano e para a República da África do Sul não diminuiu significativamente”, no cômputo geral, "o volume de emigrantes aumentava com a aproximação da fronteira" (MONTEIRO, 1994: 211). Importa aqui citar que segundo informações das autoridades administrativas da região, em 1973, dentro da zona dos Ambós contavam a volta de 6000 trabalhadores alémfronteira, sendo 1300 do Concelho do Cuamato, 2800 do Concelho do Cunhama e 1900 da Circunscrição de Namacunde (idem, p. 211).

A. Keese (2015: 237) salienta que a região do Cunene (que, durante muito tempo, pertenceu ao distrito angolano de Huíla) estava entre as mais baixas na escala de prioridades de desenvolvimento colonial de entre todos os distritos e subdivisões de Angola. O futuro distrito do Cunene é um exemplo particularmente notável das ambivalências, improvisações e contradições que caracterizam a reforma do pós-Segunda Guerra Mundial, não só no caso mais específico português, mas também no caso dos estados coloniais europeus tardios na África Subsariana em geral. A região pode ser comparada a qualquer parte marginal de um território colonial, "subdesenvolvida" mesmo até para os padrões portugueses. No início da década de 1950, os funcionários e planeadores portugueses tiveram de reajustar as suas políticas regionais, numa tentativa de melhorar a face do colonialismo português em Angola, e este processo teve finalmente de incluir as regiões próximas do rio Cunene, que durante muito tempo tinham sido território totalmente negligenciados (KEESE, 2015: 240).

Santa Clara é o mais importante posto fronteiriço da província, fazendo par com a localidade de Oshikango (Namíbia). Constitui um local de intenso comércio e de passagem de pessoas provenientes de todos os pontos de ambos os países, que circulam entre os dois territórios.

De acordo com o Plano de Urbanização da Cidade de Ondjiva, a região apresenta uma constituição geológica particular, estando inserida na denominada Bacia de Sedimentação do Cuanhama-Etocha, do quaternário, e segmento estrutural da vasta Bacia do Kalahari. Constitui parte integrante da subunidade geormorfológica denominada por Marques (1977) como Depressão Endorreica do Cuvelai-Lueque"7 (REPÚBLICA DE ANGOLA, GOVERNO DO CUNENE, 2005: 24).

\footnotetext{
7 “Região residual da aplanação do Terciário médio, recoberta por espessos depósitos arenosos eólico-fluviais. Os materiais litológicos que compõem esta bacia de sedimentação são diversos, sendo a sua constituição mineralógica
} 
As dinâmicas formais/informais e modus operandi da mobilidade da população fronteiriça do sul de Angola -

Sónia Cristina Cardoso dos Santos Silva

\section{Local da pesquisa}

Geograficamente, este estudo circunscreve-se à província do Cunene, na República de Angola $^{8}$, e à região da Ovambolândia/Oshikango, na República da Namíbia ${ }^{9}$, enquanto territórios habitados pelos Ovambo, Himba e Herero, que interatuam há muitos séculos.

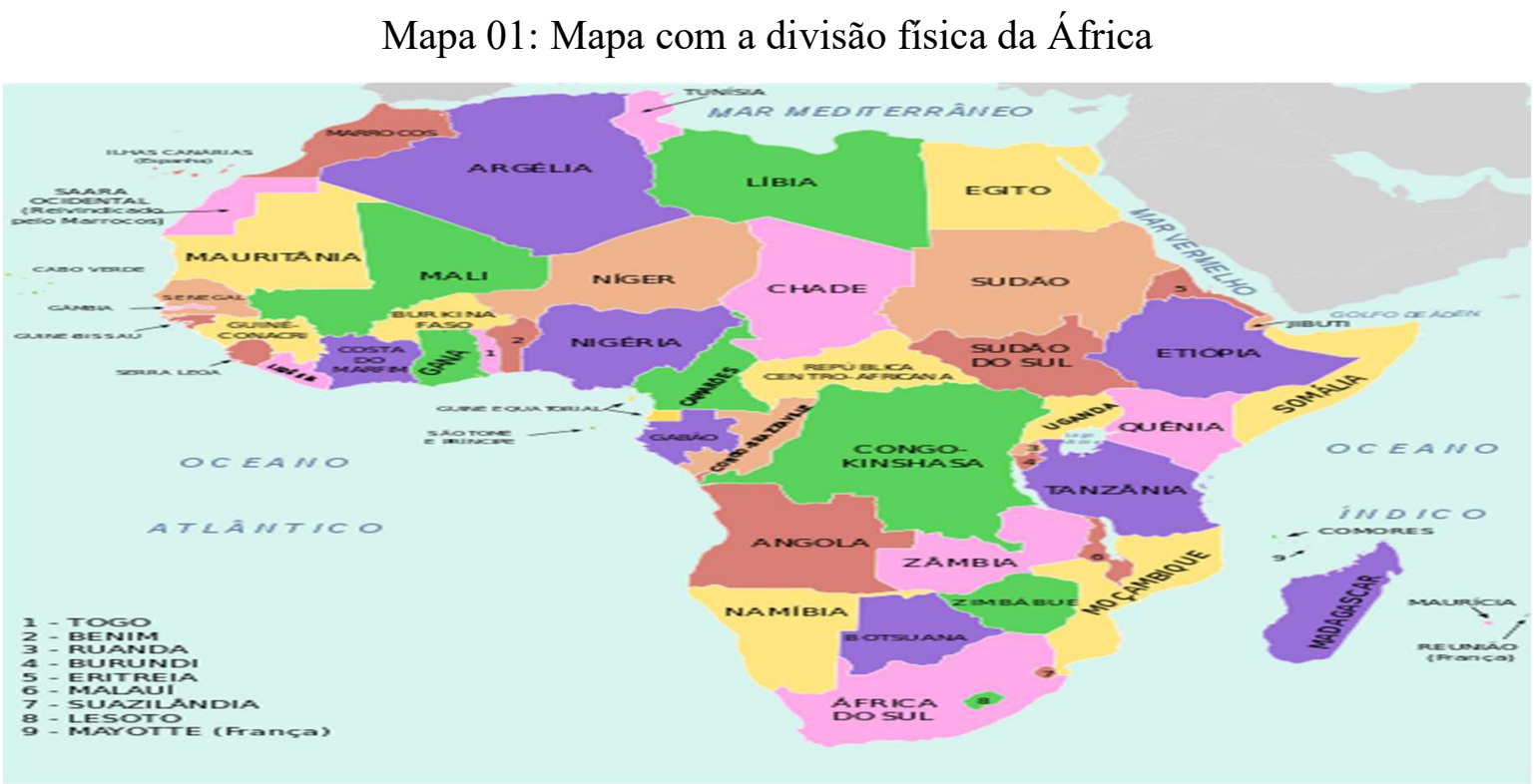

Fonte: CC-BY-SA, Fsolda, 2014.

O estudo das dinâmicas ocorridas no seio dos povos fronteiriços relativamente à mobilidade na fronteira e a gestão de recursos enfatiza que "nas relações dos Ambós angolanos com os seus vizinhos, adquiriram especial relevância as que se processavam com as populações

essencialmente representada por areia e argilas que se estruturam numa sequência estratigráfica de origem fluvial, definindo depósitos continentais do andar superior do Sistema do Kalahari. São também comuns arenitos ferruginosos, silicificados e calcários recobertos por areias de origem eólica, incluindo areias do Kalahari redistribuídas." Cf. República de Angola, Governo do Cunene, Plano de Urbanização da Cidade de Ondjiva, 2005, Volume I, p.24.

8 A República de Angola faz parte da região Austral e Ocidental de África, compreendendo uma superfície estimada em $1.246 .700 \mathrm{~km}^{2}$ e uma população avaliada em 24.4 milhões de habitantes. Situado na costa atlântica, o território de Angola descreve uma linha contínua de fronteira terrestre de $4.777 \mathrm{~km}$ e costeira contínua de 1.650 km. Faz fronteira terrestre com quatro países: (i) a Norte com a República do Congo, em cerca de $201 \mathrm{~km}$, e a República Democrática do Congo, em 2291 km; (ii) a Sul com a República da Namíbia, em 1.376 km; (iii) a Leste com a República da Zâmbia em 1110 km. (CGPH, 2014). Do ponto de vista histórico. o termo Angola tem origem na palavra Ngola, título real atribuido aos soberanos do antigo reino do Ndongo e Matamba. A palavra Ngola advém do grupo etnolinguistico Ambundu.

${ }^{9}$ A República da Namíbia integra a África Austral e tem como países limítrofes as Repúblicas de Angola e da Zâmbia, a Norte, o Botsuana a Leste e o Oceano Atlântico a Oeste. Do ponto de vista etno-histórico, os povos Khoisan habitaram sempre este território (Damaras e Namaqua), registando no século XIV imigração de povos Bantu, nomeadamente os Xhosas. O topónimo Namíbia é a denominação adotada pela Assembleia Geral da ONU, em 1968, para referir o território do Sudoeste Africano, pelo facto de se situar em pleno deserto do Namibe, significando àrea ou região onde não existe mais nada. Tem um território predominantemente desértico, junto à costa com o deserto do Namibe, no interior o do Kalahari. A foz do rio Cunene, a Norte, e a do rio Orange, a Sul, conformam os limites da sua costa marítima; a sua hidrografia é completa com o rio Kuiseb, no Centro do país.

ISSN: $2175-0742$ | v. 22 | n. 40 | p. 95-150 | Jul. / Dez. 2020 
na Namíbia, designadamente com a Ovambolândia, cuja população é da mesma etnia" (MONTEIRO, 1994: 286).

A investigação de campo teve lugar na fronteira sul de Angola, com maior profundidade na parte que abrange a província do Cunene e as regiões adjacentes da República da Namíbia, onde foram aplicadas 30 entrevistas. Desenvolveu-se na linha de fronteira, entre os marcos $1 \mathrm{e}$ 34, onde se encontram aldeias bastante distanciadas umas das outras. Por questões meramente logísticas, concentrou-se nos municípios fronteiriços de Namacunde - e onde há maior predominância de grupos e populações que têm na pecuária a principal atividade económica Ombadja e Curoca. Nestas três regiões, há uma predominância do grupo Cuanhama, o mais representativo dentro do grande grupo Ovambo e o que mais diretamente viveu as consequências do processo e do estabelecimento da fronteira sul.

A cidade de Ondjiva, capital da província do Cunene, encontra-se no Município do Cuanhama (que não é fronteiriço). São 3 os Municípios fronteiriços:

A. Município de Curoca. Administrativamente tem limite com a Província do Namibe, na localidade do Monte Negro, do marco 1 estende-se até ao marco 3.

B. Município de Ombadja. Do marco 3 até ao marco 15.

C. Município de Namacunde. Do marco 15 até ao marco 34, na área de Okambolokwena que administrativamente conforma-se com a Província do Cuando Cubango, através da Comuna de Savat.

Mapa 02 - Divisão administrativa da província do Cunene ${ }^{10}$

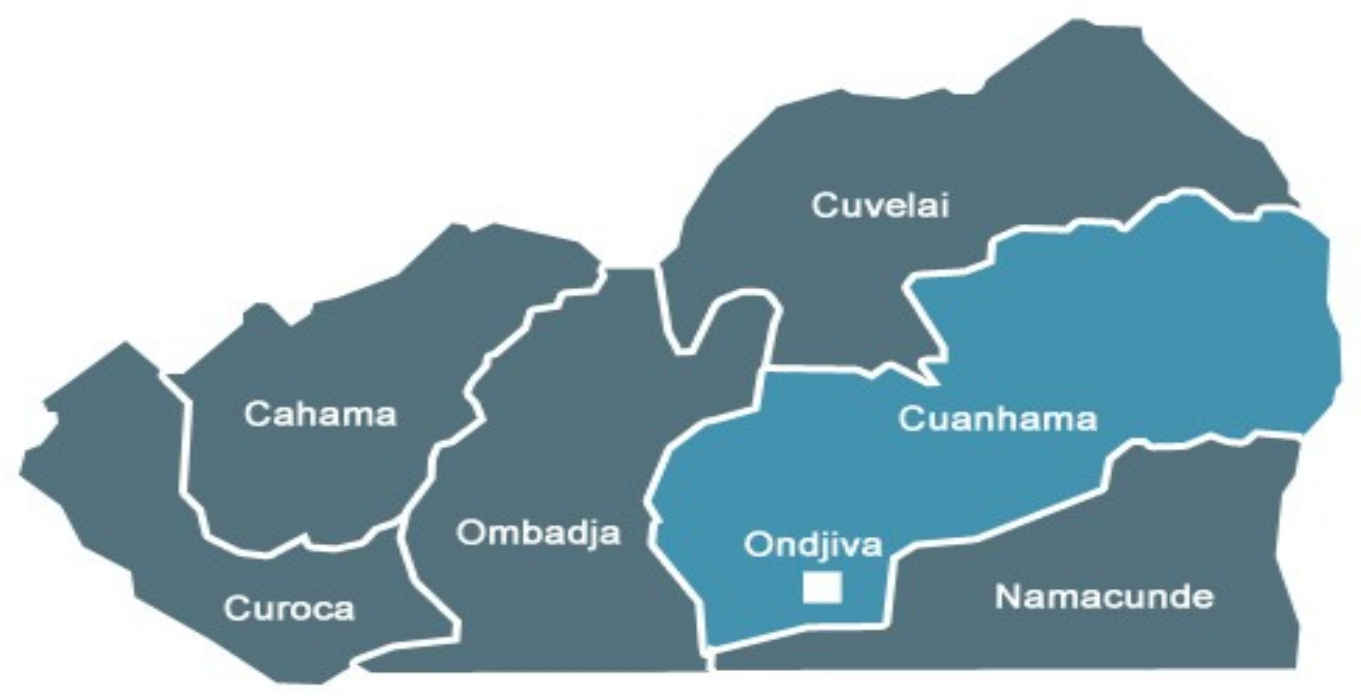

\footnotetext{
${ }^{10} \mathrm{O}$ Cunene é uma das dezoito províncias de Angola. A área que circunscreve a sua jurisdição limita-se a Norte com a província da Huila, a Sul com a República da Namibia, a Oeste com a província do Namibe, e a Leste com o Cuando Cubango. Tem seis municípios: Cuanhama, Cuanhama, Curoca, Cuvelai, Namacunde e Ombadja.
} 
As dinâmicas formais/informais e modus operandi da mobilidade da população fronteiriça do sul de Angola Sónia Cristina Cardoso dos Santos Silva

Deste modo, a pesquisa pretende contribuir para um melhor conhecimento e compreensão das relações entre Angola e Namíbia, numa dupla vertente: as dinâmicas formais, entre os dois Estados, e as dinâmicas informais, entre as populações fronteiriças. A análise tem em linha de conta que Angola viveu um longo período marcado pela presença colonial e que, depois de proclamada a independência, eclodiu o conflito político-militar, com cumplicidade externa, que influenciou profundamente o modo de vida das populações.

De acordo com o Relatório da Policia de Guarda Fronteira do Cunene, a fronteira sul de Angola entre a província do Cunene e a República da Namíbia, tem uma extensão de $460 \mathrm{~km}$, dos quais 340 são terrestres e 120 fluviais, através do rio Cunene. A fronteira sul de Angola, na sua extensão total, tem início na província do litoral Namibe e termina no Cuando Cubango, fazendo fronteira com as Repúblicas da Namíbia e da Zâmbia ${ }^{11}$ MININT, 2014). A dimensão total da fronteira sul é de $1378^{12} \mathrm{~km}$. (MININT POLICIA FRONTEIRIÇA DA PROVÍNCIA CUNENE, pesquisa no terreno em 2017/2019). Segundo ANGOP, agência nacional de notícias em 22 de Fevereiro de 2020 tratando dos "Limites fronteiriços em análise pelas autoridades angolanas", cita que a Sul, está a República da Namíbia, com uma extensão de $1.376 \mathrm{~km}^{13}$.

\footnotetext{
11 De acordo com informaçoes recentes, provenientes do Relatório da Polícia de Guarda Fronteira do Cunene, estas medições correspondem administrativamente somente à fronteira da província do Cunene com a República da Namíbia. A fronteira sul de Angola, na sua dimensão total, é fluvial (rio Cunene) do marco 1, município do Curoca, na província do Cunene, até ao Namibe, onde o rio desagua no Oceano Atlântico. Do mesmo marco 1 até ao Rivungo, já província do Cuando Cubango é terrestre, demarcada por marcos fronteiriços, a leste é fluvial através do rio Cuvango. A província do Cunene abrange os marcos 1 a 34 (a partir do marco 35 em diante, já começa a província do Cuando Cubango), é na província do Cuando Cubango que efetivamente termina a fronteira sul de Angola, Vejamos: i) Do lado angolano começando na Orla Litoral, província do Namibe com uma população estimada 568.772 habitante, área territorial de $57.091 \mathrm{~km} 2$, tem uma fronteira marítima de $480 \mathrm{~km}$; e a fronteira Fluvial com $218 \mathrm{~km}$ ii) A província do Cunene, com uma população estimada de 1.121 .748 habitantes, com uma área territorial de de $78.342 \mathrm{~km} 2$, tem uma fronteira terrestre de $340 \mathrm{~km}$ e Fluvial de $120 \mathrm{~km}$,constituída por seis (6) municípios: Cahama, Cuvelai, Cuanhama (onde se situa a capital, Ondjiva), e os municipos fronteiriços, Curoca, Ombadja e Namacunde; iii) A província do Cuando Cubango, localizada na região leste, com uma população estimada de 601.454 habitantes, área territorial de $199.049 \mathrm{~km} 2$. É constituída pelos seguintes municípios; Calai, Cuangar, Cuchi, Cuito Cuanavale, Dirico, Mavinga, Menongue (capital) Nancova e Rivungo.

${ }^{12}$ Entretanto, Segundo ANGOP, agência nacional de noticias em 22 de Fevereiro de 2020 tratando dos "Limites fronteiriços em análise pelas autoridades angolanas", cita que a Sul, está a República da Namíbia, com uma extensão de $1.376 \mathrm{~km}$. Disponível: https://noticias.sapo.ao/actualidade/artigos/limites-fronteiricos-emanalise-pelas-autoridades-angolanas, consulta em 1 de Março de 2020.

13 Disponível: https://noticias.sapo.ao/actualidade/artigos/limites-fronteiricos-em-analise-pelas-autoridadesangolanas, consulta em 1 de Março de 2020.
} 
As dinâmicas formais/informais e modus operandi da mobilidade da população fronteiriça do sul de Angola Sónia Cristina Cardoso dos Santos Silva

Mapa 03: Limites e dimensões da fronteira Sul da República de Angola

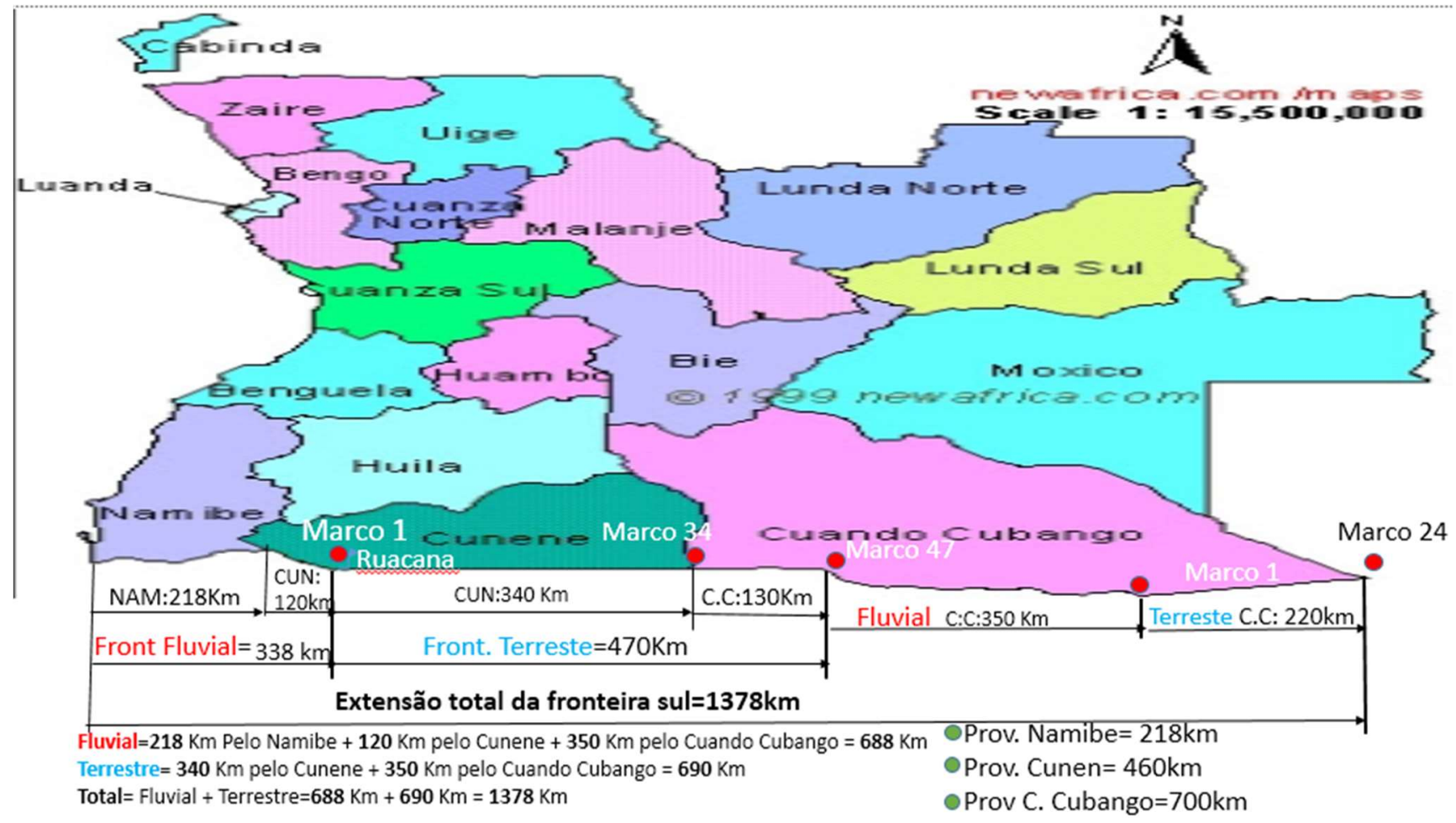

Fonte: Sónia C. S. Silva- resultado da pesquisa no terreno em 2014/2015 2017/2019 na área de fronteira e colocação das dimensões no mapa. Com Informação e Apoio da polícia de Guarda Fronteira.

\section{Síntese e descrição detalhada da metodologia e procedimentos na pesquisa Etapas da pesquisa}

Antes do trabalho de campo foi efetuada uma profunda revisão bibliográfica, recorrendo a diferentes autores relevantes, provenientes de disciplinas variadas das ciências sociais, tendo em conta as temáticas ou matérias relevantes para o tema em análise. Numa primeira fase em Portugal onde foi efectuada nossa formação doutoral e seguidamente em Angola, foram consultados trabalhos e publicações em bibliotecas e arquivos. Este levantamento permitiu definir melhor o nosso objetivo geral e identificar possíveis lacunas teórico-metodológicas em anteriores investigações bem como delinear a pesquisa. $\mathrm{O}$ trabalho de campo ancora-se em entrevistas, procurando-se na análise confrontar as respostas a estas entre si e com a literatura sobre fronteiras e sua mobilidade. Assim, a pesquisa empírica constitui efetivamente o meio de aprofundar e a perceber in loco factos e fenómenos ligados à investigação e às questões colocadas pela pesquisa realizada na região, em triangulação com a informação empírica e literatura consultada. 
Para as entrevistas foram selecionados pastores, agricultores, comerciantes, policiais de guarda fronteira (sobretudo na indicação dos marcos fronteiriços), funcionários do governo e da administração, entre outros informantes relevantes. Pretendeu-se que estas abrangessem a maior variedade possível de atores conhecedores da realidade local e mesmo, sempre que possível, envolvidos em atividades transfronteiriças relacionadas com o objeto da pesquisa. As idades dos entrevistados variam entre os 30 e os 65 anos. As pessoas entrevistadas foram selecionadas aleatoriamente, mas a escolha da amostra foi intencional, na medida em que teve como alvo informantes conhecedores da realidade local e/ou envolvidos nas referidas atividades. As identidades dos entrevistados são mantidas em sigilo por motivos de proteção de dados pessoais. A investigação foi efetuada em três fases 2014 /2015 e 2017 respetivamente.

\section{Metodologia}

A investigação, assente numa abordagem qualitativa, centrou-se no estudo de caso situacional e institucional, mediante entrevistas semiestruturadas, observação direta e pesquisa documental e bibliográfica. Uma componente importante e essencial da investigação qualitativa foi efetivamente a realização das entrevistas semiestruturadas, nomeadamente em termos da grande aprendizagem que permitiram. Na ótica de Duarte (2002: 143), este tipo de entrevistas implica uma rigorosa seleção da população e da amostra, ou seja, dos sujeitos a serem entrevistados, visto que a qualidade da amostra implica "qualidade das informações a partir das quais será possível construir a análise e chegar à compreensão mais ampla do problema delineado".

As entrevistas semiestruturadas, enquanto procedimento metodológico fundamental para as Ciências Sociais (RUQUOY, 2005; QUIVY e CAMPENHOUDT, 1998; QUEIROZ, 1998), permitiram a coleta de dados relevantes e implicaram conversas continuadas entre os informantes e o investigador, a quem competia dirigi-las em função dos objetivos, para obter maior proveito do processo. A entrevista semiestruturada é caracterizada por um tipo de entrevista mais espontânea do que a entrevista estruturada.

\section{Considerações sobre a mobilidade na região sul de Angola}

A mobilidade/migração/imigração é uma das características das populações das três províncias do sul de Angola, por vezes forçada pela natureza (enxurradas, secas, queimadas), 
outras vezes impelidas por questões políticas e de guerra, outras ainda por questões do foro pessoal/familiar. A gestão da mobilidade transfronteiriça é igualmente determinada em função de interesses económicos, tanto ao nível das comunidades como ao nível dos Estados.

Aos períodos em que a mobilidade e as motivações das populações foram fundamentalmente condicionadas por políticas coloniais e por conflitos armados, segue-se, com o fim da guerra civil, uma etapa em que a mobilidade populacional volta a estar primordialmente relacionada com fatores ligados aos recursos naturais essenciais a sobrevivência humana, como a terra, e, em menor escala, à atividade comercial.

Segundo Barbieri (2007) a mobilidade populacional pode ser uma mudança de residência pendular e/ou sazonal, ou permanente - migração. A mobilidade deriva de fluxos relacionados com a dinâmica dos ciclos de vida pessoal, familiar e comunitários, por sua vez motivados por questões pessoais ou por fatores contextuais, sejam mudanças estruturais nas comunidades, regiões ou países, ambientais, por alterações nas agendas políticas, de transportes e comunicações.

Quando os fluxos não são programados e escapam ao controlo das entidades estatais, a mobilidade populacional provoca, regra geral, pressão adicional, concentrada sobre a oferta de recursos naturais.

Junto à fronteira em análise, vivem sobretudo povos de origem bantu, ali chegados há séculos. Contrariamente à maioria das outras províncias angolanas, no entanto, existem no Cunene representações significativas de povos que não são de origem Bantu. Etnologicamente existem grupos étnicos Koysan, (não-bantu, nómadas que vivem da recolha de frutos silvestres e da caça), e Ovambos, (que se subdividem em Kwanhamas, Cuamatos e Muvales, Nyanecas, Humbes e Hereros, que se subdividem em Mucahones e Mutuas). Contudo, a língua que predomina, ou a mais falada pelas populações, é o Kwanhama, de linhagem Bantu.

\section{O Grupo Etnico Ovambo}

Em relação aos Ambós/Ovambo, segundo Redinha (1973: 73), pensa-se que a palavra Ambós advenha de Ova-ambo ${ }^{14}$, termo usado pelos Hereros da Damaralândia para identificar

\footnotetext{
${ }^{14}$ Ova-ambo ou Ovambo é uma palavra composta pelo prefixo ova (plural) e pelo radical mbo, que significa avestruz. Não "sendo correcto dizer-se ovambos para exprimir o plural em português, tratar-se-ia de um duplo plural. Neste contexto é aconselhável a grafia Ambó no singular e Ambós no plural. OvAmbó e Ovampo, mesmo que por vezes indistintamente por influência da Namíbia, referem-se a etnias diferentes. A etnia designada por
} 
As dinâmicas formais/informais e modus operandi da mobilidade da população fronteiriça do sul de Angola Sónia Cristina Cardoso dos Santos Silva

os seus vizinhos do Norte, ou a região habitada por estes. De acordo com o mesmo autor, os registos apontam a existência de subgrupos étnicos: Cuanhamas, Cuamatos, Vales, Cafinas e Dombolas, num quadro em que a "endogenia tribal favoreceu a coesão destes subgrupos, apesar da existência de um substrato étnico comum, formada antes da organização tribal”. (MONTEIRO, 1994: 235). Importa aqui recordar que os Cuanhamas consistem no maior subgrupo e também o mais representativo na nossa investigação.

Para Estermann (1983: 21), “os povos Ovampo igualmente designados de Ovambo ou Ambós, integram os Bantu, localizados no espaço Norte da Namíbia e a Sul de Angola, vivendo na margem esquerda do rio Cunene, e integrando doze (12) subgrupos". Redinha (apud MONTEIRO, 1994: 69-70) refere que os "Ambós são povos banto, e que desceram da região dos grandes lagos para sul do continente africano", tendo-se dirigido provavelmente para a zona do Cubango, infletindo seguidamente para Oeste, tendo-se fixado a sul do paralelo $18^{\circ}$, nos limites da Ovambolândia, território fronteiriço namibiano, contíguo ao território Ambó angolano. De acordo com Rodrigues Areias e Roland Kaehr (1992: 13), os Ambós, anteriormente designados de Banctuba ${ }^{15}$ consistem num "grupo étnico que ocupa a região delimitada pelos rios Cunene e Cubango, território angolano, e pelas coordenadas dos paralelos $16^{\circ}$ e $18^{\circ} 30^{\prime}$, latitude sul, estendendo-se assim até perto do lado Etocha. Esta região, com superfície aproximada de $800000 \mathrm{~km}^{2}$ e altitude média de $1100 \mathrm{~m}$, encontra-se repartida, com superfícies aproximadas, entre Angola e a Namíbia, por um troço de fronteira de cerca de 360 km de extensão"16 (MONTEIRO, 1994: 18).

Monteiro salienta que para tratar o povo Ambó, torna-se importante ressaltar que:

a expansão deste povo, na sua última fase migratória, se processou de sul para Norte continuar, isto é, da Namíbia para Angola. Era nesse sentido que se orientava o seu dinamismo expansionista, pensando então que pudesse aflorar

\footnotetext{
'Ovambo' naquele país é em Angola a que se classifica como 'Ambó' e aos 'Ovampo' no mesmo território correspondem em Angola os Nhaneca-Humbe” (Redinha, 1973 apud. Monteiro, 1994: 70).

${ }^{15}$ Banctuba provém do termo gentílico $n$ 'cutuba, pele de boi pendurada na cintura, que era na época a peça de vestuário tradicional usada pelos homens.

${ }^{16}$ Do lado angolano, o grupo étnico em referência integra "118 mil habitantes (contra cerca de 415000 na Namíbia), habita uma zona da atual província do Cunene que abrange, em continuidade geográfica, as seguintes divisões administrativas, identificadas pelas designações atualmente em vigor: o Município do Cuanhama, com as comunas da sede (N'Djiva), da Môngua, do Evale, do Nehone e do Embundo ou Chimporo; o Município de Namacunde, constituído pelas comunas da sede e do Chiede; e ainda a norte, a Comuna da Mupa do Município de Changongo, a Comuna do Cuamato, e ainda parte da Comuna da Naulila, ambas do município do mesmo nome". $\mathrm{O}$ autor considera que não existem Ambós fora destes limites, de forma representativa. Entretanto, de acordo com a Carta Ëtnica de Angola de 1970, a representação da etnia Ambó estende-se até ao norte do paralelo $16^{\circ}$ de latitude sul (Monteiro, 1994: 18).
} 
As dinâmicas formais/informais e modus operandi da mobilidade da população fronteiriça do sul de Angola Sónia Cristina Cardoso dos Santos Silva

em futuras revindicações sobre a definição do espaço territorial do povo Ambó dividido em fronteiras de criação europeia (MONTEIRO, 1994: 70).

O mesmo autor refere ainda:

efetivamente o centro Cultural da chamada nação Ovambo situa-se na Ovambolândia, a norte da Namíbia, território que adquiriu o estatuto de autonomia em meados de 1973, e cujo peso demográfico, incluindo os núcleos de residentes noutras regiões deste país, representa aproximadamente $50 \%$ da população namibiana (MONTEIRO, 1994: 19).

Segundo Monteiro (1994:79) ${ }^{17}$, em 1970 os Ambós ou Ovambos (de acordo com a designação sul-africana) somavam 414752 na Ovambolândia (Namíbia), subdivididas nos seguintes subgrupos étnicos:

Quadro 01: Ambós na Ovambolândia

\begin{tabular}{|l|c|c|}
\hline Subgrupo & População & Percentagem no total dos Ovambo \\
\hline Kuanyamas & 153461 & $37 \%$ \\
\hline Ndongas & 116133 & $28 \%$ \\
\hline Kuambis & 49771 & $12 \%$ \\
\hline Kgandjeras & 33181 & $8 \%$ \\
\hline Mbalantus & 29033 & $7 \%$ \\
\hline Kualuthis ou Kulundis & 20730 & $5 \%$ \\
\hline Eundas ou Kualonkatis & 12443 & $3 \%$ \\
\hline
\end{tabular}

Fonte: Monteiro (1994:79)

À semelhança do que ocorre em Angola, a maior percentagem cabe aos Cuanhamas que:

$\mathrm{Na}$ Namíbia se concentram numa faixa ao longo da fronteira entre os marcos 13 e 41 e, em profundidade, se estendem até Oshakati, povoação que dista da fronteira. Na Namíbia é também o subgrupo mais importante e o único que ocupa uma zona contígua dos territórios Namibiano e Angolano, sendo de salientar que em Angola os Cuanhamas estão em inferioridade numérica, mas o seu espaço é mais extenso. (...) à data do convênio em que foi definida a fronteira sul de Angola (1886), a maioria dos Cuanhamas ficou em território angolano. Após o termo das campanhas de ocupação do sul, verificou-se um autêntico êxodo de elementos desta etnia para o outro lado da fronteira (...). (MONTEIRO, 1994: 80).

\footnotetext{
${ }^{17}$ Dados fornecidos pelas autoridades sul-africanas, retirados do censo de 1970 da Namíbia, então ainda não publicados.
} 
As dinâmicas formais/informais e modus operandi da mobilidade da população fronteiriça do sul de Angola -

De acordo com o recenseamento administrativo de 1973, o número global dos Ambós em Angola era de 118.181, distribuídos pelos seguintes subgrupos ${ }^{18}$

Quadro 02: Ambós em Angola

\begin{tabular}{|l|c|c|}
\hline Subgrupo & População & Percentagem no total dos Ovambo \\
\hline Cuanhamas & 90581 & $76,7 \%$ \\
\hline Cuamatos & 18517 & $15,7 \%$ \\
\hline Vales & 8091 & $0,7 \%$ \\
\hline Dombondolas & 84 & $0,1 \%$ \\
\hline
\end{tabular}

Fonte: Monteiro (1994:80)

De acordo com o Censo 2014 (INE, 2016), a província do Cunene tem um total de 990 087 habitantes, sendo 462056 do sexo masculino e 528031 do sexo feminino. Em 2013, os dados estimados apontavam para 617487 habitantes, valores utilizados na elaboração do Plano de Desenvolvimento do Cunene 2013-2017, o que traduz uma diferença de 373000 habitantes.

Quadro 03 - População do Cunene (POR MUNICÍPIO, 2014)

\begin{tabular}{|l|l|}
\hline Curoca (ex-Oncocua) & 41087 \\
\hline Cuvelai & 57398 \\
\hline Cahama & 70061 \\
\hline Namacunde & 142047 \\
\hline Ombadja (ex-Cuamato) & 304964 \\
\hline Kwanyama & 374529 \\
\hline Total & 990087 \\
\hline
\end{tabular}

Fonte: INE, Censo 2014 (Cunene, 2016) adaptado por Mwaikafana (2018: 57).

A vida na província do Cunene é hoje a síntese de diferentes influências, acumuladas durante séculos. As migrações Bantu, a colonização europeia e portuguesa, os contactos com povos vivendo do outro lado da fronteira, criaram uma forma peculiar de estar e de ser própria dos povos que a habitam permanentemente. A colonização europeia traçou limites fronteiriços políticos que não foram suficientes para levantar muralhas intransponíveis. A cultura - a língua,

\footnotetext{
18 “Os Cafimas e os Dombondolas são dois grupos sem expressão no seio do grupo Ambó. Quanto aos Cuanhamas cerca de 99\% estavam radicados no Concelho do Cuanhama (Pereira d'Eça) e na sua circunscrição de Namacunde, fora dos limites destas duas áreas administrativas, a presença de elementos deste grupo não tinha significado e limitava-se a 37 eumbos (famílias), disseminados por seis mucundas (conjunto de eumbos), de Humbes, três delas situadas na margem direita do rio Cunene, no posto de Mucope, e a 186 eumbos ou famílias espalhadas por três mucundas: posto da Mupa (circunscrição de Cuvelai) onde predominavam os Vales, estes do grupo Ambó. A circunscrição de Namacunde era genuinamente Cuanhama; e como elementos estranhos assinalar apenas a presença de nove famílias de Umbundos que se fixaram nas proximidades das povoações de Namacunde e de Chied" (Monteiro, 1994: 81-82).
} 
As dinâmicas formais/informais e modus operandi da mobilidade da população fronteiriça do sul de Angola -

a forma de amanhar a terra, cuidar do gado, e outras manifestações culturais - é comum aos povos que vivem em ambos os lados da fronteira, originando fortes traços de partilha identitária.

As características da vida doméstica e da atividade económica da população que vive no Cunene, ao longo das linhas de fronteira do Sul de Angola, têm muitos elementos comuns aos que se encontram na da restante população do território. As etnias Muhimba, no município de Curoca, os Mumbadja, no Ombadja e, os Kwanhama do município do mesmo nome e de Namacunde, cultivam com relativa intensidade o milho, o massango, a massambala, e criam essencialmente gado bovino.A maioria da população vive, assim, da agricultura e da criação de gado, sendo cada vez mais frequente uma pequena atividade de comércio transfronteiriço. Ao longo da fronteira vivem aproximadamente 78 mil pessoas, distribuídas por 16800 quimbos. ${ }^{19}$

Quadro 04: População fronteiriça na Província do Cunene

\begin{tabular}{|c|c|c|c|}
\hline $\mathbf{N} / \mathbf{O}$ & Designação & Área abrangente & $\mathbf{N}^{0}$ população \\
\hline 01 & UPGF ${ }^{*}$ CUNENE & $\begin{array}{l}\text { A cidade Ondjiva, capital da província do } \\
\text { Cunene, no município do Cuanhama. } \\
\text { (não é município fronteiriço) }\end{array}$ & 965288 \\
\hline 02 & SUBUN-KALUEQUE & Povoação e arredores & 23000 \\
\hline 03 & PGF** DO NHANDE & Área do Nhande & Nómada \\
\hline 04 & PGF DO CHIMUACA & Área de chimuaca & 8992 \\
\hline 05 & PGF DO RUACANA & Marco 1 ao Marco 3 & 1260 \\
\hline 06 & PGF DO MARCO-5 & Marco 4 ao Marco 7 & 1810 \\
\hline 07 & PGF DO MARCO-9 & Marco 8 ao Marco 10 & 6440 \\
\hline 08 & PGF DO MARCO-12 & Marco 11 ao Marco 14 & 9006 \\
\hline 09 & SUBUN - NAMACUNDE & Mukuanan ao Marco 21 & 670 \\
\hline 10 & PGF DO MARCO-16 & Marco 15 ao Marco 17 & 2630 \\
\hline 11 & PGF DO MARCO-19 & Marco 18 ao Marco 20 & 16200 \\
\hline 12 & PGF DO MARCO-22 & Marco 21 ao Marco 23 & 2800 \\
\hline 13 & PGF DO MARCO-25 & Marco 24 ao Marco 26 & 1840 \\
\hline 14 & PGF DO MARCO-30 & Marco 27 ao Marco 32 & 3014 \\
\hline 15 & PGF DO MARCO-350 & Marco 33 ao Marco35 & 418 \\
\hline \multicolumn{3}{|c|}{ TOTAL População Fronteiriça } & 78080 \\
\hline
\end{tabular}

UPGF - Unidade de Polícia de Guarda Fronteira

** PGF - Polícia de Guarda Fronteira

\footnotetext{
${ }^{19}$ Termo proveniente das línguas/dialetos nacionais/locais que designa um conjunto de habitações pertencentes à mesma família.
} 
Fonte: Relatório da Polícia de Guarda Fronteira do Cunene (construído com base em informações das autoridades tradicionais).

O Quadro 3 apresenta a população por relação com os marcos fronteiriços. Os números, porém, não são fixos. Em função das estações do ano, há movimentos populacionais. As populações deslocam-se para o interior da província em busca de pastos ou terreno para agricultura de subsistência, pelo que os dados demográficos variam permanentemente. Este padrão de mobilidade está bem presente nas populações locais. Quando questionado como se processava a mobilidade nos três períodos históricos, bem como quais os mecanismos de controlo da população existente o entrevistado 13 (polícia de guarda fronteira no Cunene, 54 anos) afirmou: "Devido a estas movimentações permanentes, a Polícia de Guarda Fronteira, no pós-independência, atualiza trimestralmente os dados, para que reflitam de forma mais aproximada a realidade. No período pré-colonial era o sobado quem controlava a população. Já no colonial o sobado não deixou completamente o controlo, mas submetia-se às políticas e ao controlo dos dois lados da fronteira".

\section{Mobilidade na fronteira sul na Época pré-colonial}

A mobilidade de pessoas ao longo do que é atualmente o traçado da fronteira AngolaNamíbia faz parte integrante das dinâmicas das relações étnicas já seculares, por motivos económicos, culturais ou familiares. Quanto à importância que os africanos, nomeadamente os angolanos, dão às fronteiras políticas, esta situa-se "acima das fronteiras e indiferentes a elas" (SERRÃO e MARQUES, 2001: 268). Persistem laços familiares e culturais, rotas migratórias, as trocas comerciais e fidelidades políticas entre povos limítrofes. A pesquisa realizada corroborou precisamente esta realidade, que as populações do Sul de Angola e Norte da Namíbia vivenciaram ao longo dos tempos. Antes do estabelecimento das fronteiras, os africanos/angolanos podiam deslocar-se e fixar-se num ou noutro território sem grandes limitações, usufruir dos seus recursos em função das suas necessidades imediatas, como a alimentação, construção de habitação, pasto para o gado, água para os diferentes fins, construção de instrumentos de trabalho ou de defesa, ou mesmo para comércio ou pagamento de tributos. Esta mobilidade, porém, não impedia a existência de uma noção de pertença a um determinado Estado ou reino.

A história do continente mostra, por exemplo, o quanto o deserto foi dinâmico devido às rotas de caravanas. Carvalho (1997: 27) dá-nos indicações de como os povos do Namibe 
gerem de maneira inteligente os recursos naturais disponíveis: “o deserto não constituiu nenhum obstáculo [...] e nem parece ser insuperável à existência humana”. Os Ovambo, que mesmo antes da colonização habitavam e se deslocavam livremente entre o Norte da Namíbia, hostil pela vastidão do deserto, e o Sul de Angola, banhado pelo rio Cunene, partilhavam, já nessa época, pastagens e água.

Os processos políticos, as atividades económicas, os movimentos culturais, a gestão dos recursos naturais, as relações 'internacionais', a dinâmica do quotidiano, pertenciam a uma dimensão filosófica da vida sui generis, parecendo dispensar fronteiras geográficas demarcadas por linhas imaginárias com o complicado cálculo de latitudes, de graus, minutos e segundos, ou por acidentes naturais na esfera orográfica e hidrográfica de uma teoria que a outros pertencia.

Tal não significa uma ausência total da noção de fronteira entre os africanos. Sempre que necessário, faziam valer os direitos de soberania sobre determinado território, respeitando a integridade dos espaços físicos e culturais doutras entidades políticas.

Podemos aferir que as populações do Sul de Angola, antes do estabelecimento da fronteira, se moviam livremente. As fronteiras eram móveis, sem existência de acordos jurídicos, mas respeitadas entre si, com controlo de movimentos populacionais. Este controlo era exercido pelos sobados das respetivas circunscrições, numa lógica de informalidade, baseada no conhecimento pessoal dos indivíduos, a quem se reconheciam direitos de propriedade e/ou usufruto relativamente a terra, água e pastagens.

Pequenos produtores agrícolas familiares e criadores de gados tradicionais dependem das chuvas para a sua atividade sendo ainda pouco significativa a existência de infraestruturas para a reserva de água, visando compensar os prolongados períodos de seca, de acordo com o Plano de desenvolvimento da Província do Cunene (PDPC, 2014). Segundo Monteiro, (1994: 153) “A alternância entre inundações e períodos de seca intensa permite alguma exploração agrícola, sobretudo a criação de gado" ou seja de secas prolongadas, que contrastam com períodos de excesso de chuvas com grande incidência na sua região mais a Sul caracterizam a região. Na altura do capelongo (secas prolongadas), observava-se o deslocamento dos rebanhos pelo rio Cunene "reafirmando esta como a principal atividade do Cuamato, tão cobiçada pelos nativos do Cuanhama" (PAULA, 2016: 104).

Relativamente às dinâmicas económicas, a transumância, característica da região, não se pode resumir a um simples movimento de gado sem nexo. Antes, "ela resulta de tendências ancestrais filiadas no nomadismo, que chegaram até aos nossos dias por obediência da tradição, 
ela constitui uma técnica de pastoreio imposta pela necessidade de adaptar a exploração pecuária às condições ecológicas da região (MONTEIRO, 1994: 183).

\section{Mobilidade na fronteira sul de Angola na época - colonial}

Não obstante a existência de fronteiras impostas dividindo povos, não se pode considerar que os movimentos migratórios em Angola, ou na África em geral, tenham terminado. As populações continuaram o seu movimento, fosse em busca de segurança, de emprego, ou mesmo em contexto de negócios informais, pelo que o traçado fronteiriço não alterou significativamente as relações culturais.

De acordo com Monteiro (1994: 207-206), a população Ambó está repartida por Angola e pela Ovambolândia “onde se situa o centro cultural deste grupo étnico, o que constitui reconhecimento de uma estrutura cultural uniétnica", atestando a permanência de laços de união entre uns e outros, sendo a fronteira apenas uma linha convencional, sem grande significado para a população.

O contexto histórico, cultural e político das populações angolanas que vivem em regiões de fronteira internacional dá-nos indicações de épocas em que, perante a presença colonial portuguesa, os 'nacionalismos' implicavam, por um lado, constantes movimentações de populações inteiras e, por outro, que essas movimentações se dessem em direção a zonas onde a escassez de água para as pessoas, para o gado e para a agricultura não constituísse um problema adicional. As populações procuravam água em função de necessidades que se revelavam semelhantes, e mesmo as motivações culturais, políticas e económicas da sua procura eram, também elas, semelhantes para povos de Angola, Namíbia, Zâmbia, o que justifica a aproximação e fixação junto a rios comuns: “Aqui no Cunene a fronteira apareceu mais tarde... passou mesmo no meio de uma família" ${ }^{20}$ (UDELSMANN RODRIGUES, 2011).

Embora durante o período colonial se verificasse um certo controlo, com algumas restrições à mobilidade na fronteira impostas pelos Estados, regra geral os contactos entre as populações que residiam nas proximidades da fronteira eram mais assíduos, uma realidade que se manteve. Quando questionado sobre o significado de fronteira e qual o seu impacto na vida da população do Sul de Angola e Norte da Namíbia, o entrevistado 2 (sexo masculino, pastor

\footnotetext{
${ }^{20}$ Documentário - Esta fronteira não existe (This Border Does Not Exist) - documento produzido para fins científicos no âmbito do projeto de investigação Fronteiras e Identidades em Africa, financiado pela Fundação para a Ciência e a Tecnologia (PTDC/AFR/098339/2008). Cristina Udelsmann Rodrigues, in Conferência Fronteiras e Identidades em África, ISCTE-IUL, 10-12 de dezembro, 2011.
} 
As dinâmicas formais/informais e modus operandi da mobilidade da população fronteiriça do sul de Angola Sónia Cristina Cardoso dos Santos Silva

de 45 anos de idade) declara: "A fronteira alterou, mas não impediu na totalidade contactos entre as populações".

Aparício (2000: 225) refere que outro aspeto de particular importância durante a presença colonial, particularmente na época da delimitação da fronteira sul de Angola, foi a diferença entre as políticas praticadas pelas potências ocupantes.Mandume (rei dos Cuanhamas) e muitos outros jovens foram educados por missões alemãs. A rivalidade entre as potências foi instrumentalizada pelos chefes Cuanhamas, e Nande, soberano que reinou de 1904 a 1908, foi um bom exemplo desse jogo diplomático, tentando obter dividendos dos dois lados.

Paula (2016) recorda que Carlos Roma Machado de Faria e Maia, personagem que participou na delimitação da fronteira sul, apontou vezes sem conta, em textos dirigidos a Portugal e publicados tanto no Boletim Geral das Colónia da época como em meios posteriores, "pessoas cruzando a fronteira". Os portugueses, por seu turno, empregavam os nativos em obras públicas, como abertura de estradas, entre outros trabalhos, desde o princípio da pacificação. $\mathrm{Na}$ base da decisão de passar para o outro lado da fronteira, para além da remuneração baixa ou mesmo inexistente:

a sua insatisfação com as questões burocráticas introduzidas pelo governo Português, como a cobrança demasiada de impostos e obrigatoriedade de trabalho compulsório em obras públicas. Em contrapartida, os mandatários do sudoeste africano, cientes da necessidade de atrair mão-de-obra para sua região e sabendo dos problemas ocorridos no sul de Angola, ofereciam para essas pessoas o que elas consideravam melhores condições para viver, que incluía a redução de impostos e oportunidade de emprego nas minas de Otawi. (PAULA, 2016: 167)

No período colonial, de acordo com as informações resultantes das entrevistas locais consideradas no quadro desta investigação, a circulação de populações na fronteira sul continuou, de bem que de forma mais controlada e condicionada à apresentação de documentos exigidos pelas autoridades dos dois Estados, o português e o sul-africano.

De acordo com os relatos resultantes das entrevistas, e quando se lhes colocou a questão sobre a mobilidade populacional no período do apartheid $^{21}$ :

a circulação de pessoas era muito restrita. Os indivíduos receavam ser confundidos com elementos da SWAPO, correndo o risco de confronto com as autoridades sul-africanas. Mesmo assim, registavam-se frequentes cortes

\footnotetext{
${ }^{21}$ Apartheid foi um regime de segregação racial adotado de 1948 a 1994 pelos sucessivos governos do Partido Nacional na África do Sul, no qual os direitos da maioria dos habitantes foram cerceados pelo governo formado pela minoria branca.
} 
As dinâmicas formais/informais e modus operandi da mobilidade da população fronteiriça do sul de Angola Sónia Cristina Cardoso dos Santos Silva

na rede de separação, com violações da passagem de um lado para o outro da fronteira. (ENTREVISTADO 16, SEXO MASCULINO, 34 ANOS, PGF)

Na luta pela independência do país, em confronto com o regime fascista e de apartheid da África do Sul, a SWAPO solicitou auxílio de Angola e criou, em território angolano, postos avançados de preparação para a guerrilha. Essas bases eram bombardeadas pelo exército sulafricano, num período em que Angola já se encontrava independente da presença colonial, mas vivendo um momento não menos conturbado da sua história, o período de guerra civil.

Conforme se pode ler em Paula (2016), já em 1927 a delimitação da fronteira:

não teve muito significado no dia-a-dia dos nativos da região, que permaneciam migrando de um lado para outro. Ao fim do seu artigo, Carlos Roma Machado conclui que acredita que nenhum dos esforços citados seriam suficientes para frear a emigração da região, visto que seriam ações que levariam algum tempo para serem concluídas. Assim sugere que diante o povoamento eminente dos Ovambo angolano, sejam promovidas políticas de povoamento com nativos do planalto Bié, por exemplo. (PAULA, 2016: 173).

Caracterizando a mobilidade no período colonial, Henriques (1997), refere que com a crescente procura de novas matérias-primas:

as caravanas tornam-se pequenas, dinâmicas, caracterizando-se por uma cada vez mais acentuada profissionalização dos seus membros, (...) com carregadores assalariados", em função da mercadoria e do 'porto' de destino se determinavam as rotas de circulação levando por sua vez a "modernização do comércio africano. (HENRIQUES, 1997: 73)

Estas características são reveladas também pelas entrevistas:

A mobilidade na fronteira no período colonial era controlada pelas respetivas administrações, tanto em termos de enquadramento legal como no terreno. No quadro da política interna do apartheid e na tentativa da sua expansão para o Sudoeste Africano, foi levantada pelo governo namibiano uma rede metálica, com policiamento presente nas proximidades da fronteira, de ambos os lados. Esta rede, colocada a aproximadamente dois a três metros da linha de fronteira, servia para o controlo do movimento migratório de pessoas e bens, com predominância para a movimentação de gado, em busca de pastagens, para minimizar os efeitos da estiagem nos dois países. Esta intervenção, levada a cabo em 1984, ano que foi construído a picada de controlo de pegadas, criada desde o marco 22/Cunene até ao marco 47/Cuando Cubango, surge na continuidade do trabalho efetuado pelas autoridades do apartheid. A referida picada servia para o controlo, no perímetro da fronteira, de pegadas que revelassem possíveis penetrações de guerrilheiros da SWAPO - uma vez que o movimento de libertação tinha bases nesta região do território angolano. (ENTREVISTADO 14, SEXO MASCULINO, 45 ANOS, POLÍCIA DE GUARDA FRONTEIRA). 
Figura 01: Vedação destruída em portinhola (Namíbia)

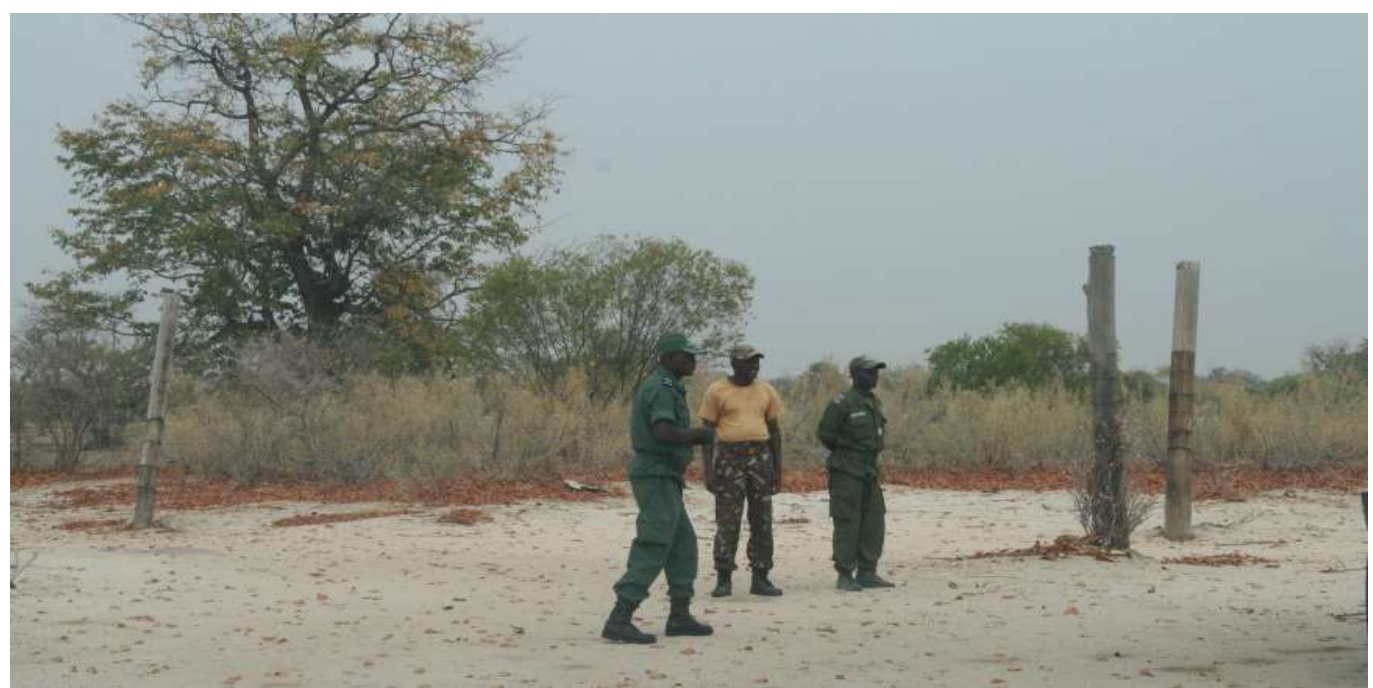

Fonte: Polícia de Guarda Fronteira, 2017.

Em conversa com um polícia de guarda fronteira no comando de fronteiras, em Luanda, com cargo de chefia, em 2017, abordando o controlo da fronteira e a gestão da mobilidade na fronteira sul de Angola, aflorou o seguinte:

Logo após a independência da Namíbia, as autoridades de Windhoek ergueram uma vedação de arame na fronteira com Angola, dando continuidade à política de segurança das fronteiras. Na vedação foram criadas portinholas, de modo a permitir acesso do gado ao pasto e a água nos dois territórios. Hoje, esta vedação já não existe. Ao longo dos últimos 15 anos, a população foi destruindo a cerca, numa atuação para a qual se identificaram razões várias: uns defendem que não devem existir barreiras entre as populações do Sul de Angola e do Norte da Namíbia, pois trata-se do mesmo povo ou grupo étnico, com usos e costumes comuns, enquanto outros destacam a ação de meliantes, que foram vandalizando e destruindo a vedação para maior facilidade de contrabando de viaturas, fuga ao fisco e outros delitos.

Durante o período colonial as autoridades portuguesas de Angola criaram pequenas lojas nas proximidades da fronteira, onde se trocavam diversos produtos para consumo humano e do gado, provenientes da produção das populações locais. Nesse contexto, alguns entrevistados referiram que no período colonial não existiam trocas com a Namíbia (entrevistada 1, sexo feminino, soba, 54 anos de idade). Segundo a mesma entrevistada, "o acesso aos recursos que garantem as atividades produtivas (terra, água, pastos) implica necessariamente uma intensa circulação. A necessidade de procura de melhores pastos e a busca de água, o acesso a serviços, e visita a familiares, força as populações a uma mobilidade permanente, ainda que controlada pela administração colonial." 
Os entrevistados no Cunene foram unânimes em afirmar que com a demarcação da fronteira, as populações (grupo étnico Cuanhama) foram divididas, tendo uma parte ficado no lado namibiano (antigo Sudoeste Africano), e outra em Angola.

"A família ficou dividida, pais de um lado, filhos e irmãos de outro" entrevistado 14, (sexo masculino, 45 anos de idade, PGF) gerando constrangimentos para as famílias, que agora se veem obrigadas a recorrer aos pontos de passagem oficiais, em locais autorizados pelos dois Estados - as chamadas “portinholas”. Estas transposições da fronteira regem-se por um tempo determinado de permanência, e não devem ultrapassar uma distância superior a 60 quilómetros para o interior de cada um dos países. Esta solução é exequível porque os indivíduos residem ao longo da linha de fronteira e são conhecidos de ambos os lados. Importa recordar que a liberdade de circulação que existia no período pré-colonial, ou anterior ao estabelecimento das atuais fronteiras, está claramente coartada. Contudo, apesar destes constrangimentos ou condicionantes, os laços culturais fortes fazem com que as populações se continuem a identificar sempre como "um único povo", com regras consuetudinárias muito próximas na essência e interpretação. O entrevistado 20 (sexo masculino, 54 anos de idade, PGF) disse:

As redes existentes na fronteira entre a Província do Cunene/Sul de Angola e a República da Namíbia nunca serviram como referência de delimitação dos dois Estados. A efetiva referência de fronteira é o rio Cunene.

Segundo Udelsmann Rodrigues (2017), a fronteira foi vedada depois da Segunda Guerra Mundial, com o objetivo de incrementar o controlo da circulação entre os dois países, tanto de indivíduos, como, particularmente, do gado. A fronteira física permite a manutenção da mobilidade transfronteiriça, mas obviamente com maiores restrições. De referir que a vedação da fronteira foi acompanhada por atos de vandalismo, com diversas tentativas de eliminação da rede. A primeira vedação erigida acabou por ser destruída em 1970, no quadro do conflito entre a SWAPO e a África do Sul.

Antes da independência de Angola, em 1975, havia menos Ovambos em Angola (cerca de 120 mil) do que na Namíbia (aproximadamente 415 mil). Nesse período, cerca de 99\% dos Cuanhamas angolanos estavam baseados no município de Cuanhama, com sede em Ondjva, e Namacunde. (KREIKE 1989: 3, apud UDELSMANN RODRIGUES, 2017; MONTEIRO, 1994: 81, apud UDELSMANN RODRIGUES, 2017: 6). 
As dinâmicas formais/informais e modus operandi da mobilidade da população fronteiriça do sul de Angola -

Sónia Cristina Cardoso dos Santos Silva

Segundo Udelsmann Rodrigues (2017: 10), as disputas coloniais na fronteira sul (Angola/Namíbia) envolveram confrontos regulares, tendo "impactado as relações entre os kwanhamas que residem dos dois lados.",22

\section{Migração e mobilidades}

Segundo Monteiro (1994: 206), “a emigração para o vizinho território da Namíbia revestia-se de extrema importância pelas suas repercussões económicas e sociais, mercê de vários fatores, entre os quis sobressaia a hábil política e a oportuna publicidade desenvolvida inicialmente pelos sul-africanos, o duro trabalho das minas passou a constituir forte aliciante para o jovem Ambó. (...)". Terminado o período de guerrilha, na ótica de Carlos Esterman (op.cit: 146, apud MONTEIRO, 1994: 207), sucede-lhe uma preocupação particular: "como ocupar os jovens, como conseguir que mantivessem o estilo europeu nas indumentárias, sem terem em sua posse os meios para permuta que era o gado, sendo que este se encontrava em posse dos mais velhos não disposto a cedências ou a "malbaratar sua riquezas com tais ninharias". Inicia-se assim o" trabalho fora da terra, a exploração mineira em Tsumeb e ao sul do Namíbe; a corrente migratória foi desviada para sul, consentindo os sobas na ausência temporária dos súbditos, mediante uma contribuição no regresso a terra" ${ }^{\text {23 }}$. Terminadas as campanhas militares do Sul de Angola, após o controlo definitivo do território pelos portugueses, "os sobas viram-se privados deste tributo, mas, libertos os jovens das guerrilhas o volume das correntes migratórias aumentou consideravelmente"; não foram adotadas relativamente a estes povos "a política de atração que as circunstâncias aconselhavam e havia sido definida, em disposições legais, pelo então Governador-Geral Pereira d'Eça" (Monteiro, 1994: 208) ${ }^{24}$.

\footnotetext{
${ }^{22}$ Após a Primeira Guerra Mundial, a Alemanha perde o território do Sudoeste Africano em cumprimento do disposto no Tratado de Versalhes (1919), sendo posteriormente administrado pela África do Sul, com base no mandato da Liga das Nações. Em 1946, já sob autoridade das Nações Unidas (que substituíram a Liga das Nações), a África do Sul recusa-se a ceder a tutela do território à ONU, seguindo-se décadas de disputa internacional sobre o território, com sucessivas resoluções da AssembleiaGeral da ONU. Pelo contrário, a África do Sul procura a anexação da Namíbia, que passaria a ser a quinta província do país, estendendo a aplicação do regime de segregação racial ao território. Após décadas de conflito entre a SWAPO e as autoridades de Pretória, a Namíbia alcança a independência em 1990.

Já do lado angolano, a penetração colonial portuguesa ocorre no início do século XX, tendo-se registado vários confrontos com o exército do rei Ovambo, Mandume. À morte do rei, em 1917, seguiu-se a derrota dos Cuanhamas.

${ }^{23}$ Dois ou três decénios antes do termo das guerrilhas, já se tinha verificado uma pequena corrente migratória, com a saída de alguns trabalhadores para Missões Católicas na Huíla e Caconda (idem).

24 "As desigualdades dos processos de administração de aquém e de além fronteira deu origem ao gradual despovoamento do baixo Cunene e dos Gambos (especialmente de Otchinjau e Cahama). A população da área dos Cuanhama ficou reduzida, nesse mesmo período, a pouco mais de um terço." A saída para território além fronteira justificava-se "os jovens diziam que o inglês não cobrava imposto e, de facto, no Ovampo não eram impostas quaisquer obrigações fiscais ao africano, regalia que não era
} 
No âmbito das políticas governamentais surgem projetos que implicam necessariamente mobilidade populacional. A Missão de Inquéritos Agrícolas em Angola (MIAA) desenvolveu um projeto na região do Cunene para desenvolver a criação e comercialização de gado. A política de intervenção local do governo - no quadro do fomento rural - seja a nível da tecnologia ou do controlo dos mercados (externo e interno), requereu legislação sobre importações e exportações de produtos e monitorização das tecnologias produtivas nas propriedades, independentemente da propriedade individual ou familiar. Essas políticas e programas do governo colonial não foram suficientes para impedir que trabalhadores rurais angolanos - sobretudo os que viviam a sul da colónia, entre eles os Ambós e os NyanekaHumbe - preferissem trabalhar nas minas no Sudoeste Africano, ou mesmo na África do Sul, onde as condições de vida e os salários eram superiores aos praticados do lado de cá da fronteira.

Machado (1956) refere a existência de quatro missões protestantes no Ovampo: duas (a Guela, finlandesa, e a Dimbo, inglesa) situadas a aproximadamente 9 quilómetros da fronteira, conseguiram fazer com que muito africanos acabassem por abandonar o território angolano tendo-se fixado nas suas proximidades. Existiam do lado angolano missões católicas, contudo sem nenhuma influência capaz de estancar o êxodo (apud Monteiro, 1994: 208).

Monteiro (1994: 209) socorre-se de Afonso Mendes (1958: 93-98) na temática do trabalho indígena. No início do século XX a exploração mineira em Tsumeb e Grootfontein (Namíbia), foi bastante divulgada, com elementos alienadores da juventude, como o aproveitamento do antigo slogan europeu que dizia "só é homem quem foi militar", transposto para a realidade africana como" só é homem quem trabalhou nas minas". O apelo das minas respondia à necessidade inicial do jovem satisfazer as suas necessidades primárias e para planear a constituição de família.

Os contratos eram celebrados por períodos de 18 meses, tendo posteriormente diminuído para 12 meses (este período nunca podia ser excedido, mesmo que essa fosse a vontade do trabalhador. ${ }^{25}$ (IDEM, p.211)

Nesse contexto, tudo se tornou vantajoso para a Namíbia uma vez que as empresas instaladas em território angolano não ofereciam condições sequer aproximadas: "um simples funcionário mineiro usufruía o equivalente a 152 escudos mensais, mas com a possibilidade de

\footnotetext{
extensiva aos restantes territórios onde somente havia isenção no primeiro ano. A data estava em vigência na Ovambolândia o imposto individual cujo montante era de 2 rands" (Monteiro, 1994:208).

${ }^{25}$ Findo o contrato, o trabalhador era repatriado e voltava a renovar o contrato na Ondângua como forma de mostrar cumprimentos das decisões. Em Angola os contratos celebrados eram frequentemente prorrogados. (Monteiro, 1994: 211).
} 
As dinâmicas formais/informais e modus operandi da mobilidade da população fronteiriça do sul de Angola Sónia Cristina Cardoso dos Santos Silva

melhorar. Alguns deles chegavam mesmo a auferir 10 libras por mês, e beneficiavam de roupa. Em Angola, porém, em 1947 a tabela de salários mínimos oscilava entre 51 e 75 escudos mensais, incluindo igualmente a alimentação, vestuário e alojamento. $\mathrm{O}$ vestuário era em qualidade inferior ao proveniente da Namíbia”. (IDEM p. 209).

De acordo com dados recolhidos pelo Governo do Distrito do Cunene junto das autoridades namibianas, os salários eram pagos em numerário aos "trabalhadores indiferenciados" e variavam consoante o sector e a atividade. Nas minas (Tsumeb) ascendia a 80 cêntimos por dia em trabalho de superfície (28 escudos), em trabalhos de profundidade equivalia a 32 escudos diários (35 no câmbio oficial) (MONTEIRO, 1994: 214).

Geralmente, os trabalhadores preferiam a indústria da pesca, e só depois os caminhosde-ferro e as minas. A pesca permitia horas extraordinárias, com a consequente duplicação do salário. Por outro lado, as condições de trabalho nas minas faziam com que muito trabalhadores regressassem em má condição física, fruto de acidentes ou doenças incuráveis. (idem, p. 217)

Mesmo que houvesse alguma correspondência entre o Rand e o Escudo no câmbio oficial, os salários praticados eram superiores ao salário mínimo em Angola (25 escudos ao trabalhador indiferenciado. ${ }^{26}$ A este propósito, Monteiro (1994: 217) refere que:

Duas décadas atrás a moeda corrente na zona dos Ambós era a da África do Sul, a única que o comerciante aceitava em troca dos seus produtos, a que era válida nas transações. A moeda portuguesa só era adquirida e nem sempre para pagamento do imposto e o seu valor era conhecido pela maioria da população... apesar da mudança operada no início da década de 1970, boa parte desta gente só se raciocinava em termos de rand ou de libra.

O contacto com novos padrões culturais no Sudoeste Africano gerou um processo de aculturação (a valores por vezes estranhos aos originais). Assim, no seio dos Ambós a língua veicular e que facilitava a sua realização profissional era o afrikaans ou o inglês, por contraste com o número reduzido que se exprimia em português. (idem)

Em termos de relação patrão/empregado, "os preconceitos raciais e da consequente necessidade de manter o africano à distância, como ser inferior, eram reduzidos ao indispensável os contactos com os trabalhadores"27 (IDEM, p. 209).

\footnotetext{
${ }^{26} \mathrm{O}$ confronto entre os quantitativos salariais em vigência na Namíbia e em Angola, relativamente ao salário diário não constituía problemas, mas o mesmo não sucedia no trabalho contratual,

${ }^{27}$ Por exemplo no sudoeste africano a recusa do africano em fazer algum trabalho, implicava cortes de salários, despedimento, mas não métodos coercivos; em Angola apesar de ser tratado como "ser igual", "pai e filho", o paternalismo levou a excessos de autoridade. (MONTEIRO, 1994: 211)
} 
As dinâmicas formais/informais e modus operandi da mobilidade da população fronteiriça do sul de Angola Sónia Cristina Cardoso dos Santos Silva

A partir de 1961, o contexto africano mudou e a situação alterou-se, mas os efeitos psicológicos persistem na mente dos africanos.

Pode-se concluir que o "volume de correntes migratórias para o antigo Sudoeste Africano e para a República da África do Sul não diminuiu significativamente", no cômputo geral, "o volume de emigrantes aumentava com a aproximação da fronteira" (MONTEIRO, 1994: 211). Segundo informações das autoridades administrativas da região, em 1973, dentro da zona dos Ambós registavam-se cerca de 6000 trabalhadores além-fronteira, sendo 1300 do Concelho do Cuamato, 2800 do Concelho do Cunhama e 1900 da Circunscrição de Namacunde (IDEM, p.211).

A situação em Angola era muito diferente, pois "o movimento de trabalhadores migrantes para o interior do país manteve-se estacionário. Em 1969-1970, o número de trabalhadores era de quatro milhares; entretando registou-se um decréscimo nos dois anos subsequentes, mais acentuado em 1972 (cerca de 50\%) devido a dificuldades na agricultura, com uma consequente reduzida oferta de trabalho, que voltaria a subir no ano seguinte para $3387 .{ }^{28}$ (IDEM p.212)

Surgem indícios de alterações no seio dos Ambós relativamente à "relutância do homem Ambó pela atividade agrícola" porquanto "cerca de 60\% da mão-de-obra da zona em apreço era absorvida pelo setor agrícola (sisal, tabaco, algodão, girassol e café designadamente) e 40\% pela indústria de pesca de Moçamedes e Porto Alexandre.

Subjacentes aos movimentos migratórios para o Sudoeste Africano estão motivações:

de ordem económica, a tradição, as afinidades étnicas, as facilidades concedidas além fronteira para obtenção da carta de condução de carros ligeiros, pesados e tratores, bem como o exercício da atividade comercial, e a escassez de ofertas de trabalho no sector secundário e até do sector primário, no Distrito do Cunene ou nas área limítrofes. (MONTEIRO, 1994: 216)

Sinteticamente, se por um lado as migrações para a Namíbia eram benéficas, segundo Mendes da Ponte, uma vez que se arrecadavam receitas e/ou divisas para a economia do Distrito do Cunene, sobretudo advindas da venda do seu "armentio bovino", por outro lado, e do ponto de vista económico, tais benefícios eram minorados sobretudo quando se avalia o decréscimo da população, cuja força de trabalho enriquecia o território namibiano, e também porque as

\footnotetext{
${ }^{28}$ A procura de trabalho em Angola era significativa, porém somente incluía trabalhadores com contrato escrito. A mão-de-obra rural ou equiparada no Distrito do Cunene estava geograficamente distribuída da seguinte forma: na sua maioria (75\% em 1971 e $82 \%$ em 1972) os trabalhadores dirigiam-se para o Distrito da Huila, Moçamedes e Benguela. Em 1971, 50\% dessa mão-de-obra foi absorvida pelo Distrito da Huila, com uma baixa no ano seguinte, o que se presume ser devido a adversidade do ano agrícola. Cf. Monteiro, 1994: 212.
} 
As dinâmicas formais/informais e modus operandi da mobilidade da população fronteiriça do sul de Angola Sónia Cristina Cardoso dos Santos Silva

remunerações auferidas ficavam praticamente na sua totalidade nos locais de trabalho no Sudoeste Africano, em bens de consumo (Monteiro, 1994: 216) ${ }^{29}$.

No caso concreto das fronteiras angolanas, mais concretamente a fronteira sul de Angola, os efeitos advindos da separação por uma "fronteira convencional" de populações pertencentes à mesma etnia com afinidades culturais muito profundas são vistas da seguinte forma: "A fronteira pouco conta para estas populações identificadas pela mesma origem étnica, pela mesma cultura, pela mesma língua, pelas mesmas motivações e coisas de um passado histórico comum, marcado pela índole vincadamente guerreira dos seus antepassados, que espalharam o terror à sua volta" (MONTEIRO, 1994: 86).

Segundo o mesmo autor, "o povo Ambó apresentava particularidades assinaláveis, uma vez que, ao contrário de outras populações angolanas, era influenciado por duas correntes de aculturação ${ }^{30}$ de matriz ocidental: portuguesa e a sul-africana" (MONTEIRO, 1994: 24).

\section{Mobilidade na fronteira na época pós-independência}

Depois da independência, Angola mergulha numa guerra civil (1975-2002), opondo os dois partidos políticos, MPLA e UNITA. Em 1992, decorrem as primeiras eleições multipartidárias em Angola, cujos resultados seriam contestados pela UNITA, e na sequência das quais se assiste a um ressurgimento do conflito.

Entre 1998 e o ano 2000, os conflitos que assolaram a região do Cunene levaram à paralisação da atividade agrícola e provocaram um fluxo de deslocados internos para a vizinha província da Huila. A população rural manteve-se, segundo Udelsmann Rodrigues (2017) no Oilongo, no mato, perseguida pelas tropas sul-africanas e da UNITA. Para além do conflito interno angolano, o Cunene foi ainda assolado por confrontos entre a SWAPO e a África do Sul, até à independência da Namíbia.

Para uma melhor gestão das relações entre os dois Estados, bem como das populações fronteiriças, criam-se mecanismos formais e informais.

\footnotetext{
${ }^{29} \mathrm{O}$ caráter seletivo das migrações, pois só emigravam elementos do sexo masculino, muitos dos quais acabaram por se fixar no território vizinho do Sudoeste Africano, provocou desequilíbrios sociais, sobretudo no tocante à baixa das taxas de natalidade (ausências prolongadas do marido) para um povo com elevada tendência poligâmica. (idem, p. 216-217)

${ }^{30}$ Nos dias de hoje, é muito frequente o uso do conceito de transculturação, considerado o fenómeno das zonas de contacto, ou seja, corresponde a uma noção restrita da noção de aculturação, ao contato entre culturas de força (e influência desigual).
} 
as formais, passam pelos trâmites aduaneiros, as informais passam pelo recurso a "mulas de carga", ou seja, fragmentação de mercadoria do mesmo proprietário por diversas pessoas que transportam em pequenas quantidades para darem a impressão de mero uso pessoal. Os dados de que se dispõe são, portanto inferiores à realidade, aproximando-os mais desta do lado namibiano, porque muitos operadores que fragmentam carga para entrada em Angola, procedem a despacho aduaneiro total na Namíbia. Por vezes diretamente em Oshikango mas cada vez mais, perto dos locas de aquisição em Oshakati, cerca de $60 \mathrm{~km}$ para sul. (GONÇALVES, 2010: 255).

Referindo-se à mobilidade e formas de controlo nas fronteiras, o entrevistado 23 (sexo masculino, 58 anos, responsável pelo posto de Santa Clara), em 2014 aponta "como mecanismos formais para a passagem da fronteira entre os dois Estados: no portão principal, o de Santa Clara (marco 19), é exigido o uso do passe de travessia/salvo-conduto para cidadãos que se deslocam a pé e que não se deslocam para mais de 60 quilómetros da fronteira. Para quem declara que a deslocação é superior a essa distância (como, por exemplo, Windhoek) é obrigatório o uso do passaporte, quer se trate de uma deslocação em viatura própria ou com recurso a outro tipo de transporte. A estadia tem um prazo máximo de trinta dias, podendo ser prorrogada mediante apresentação de justificação, com o aval dos serviços de emigração. Informalmente, os indivíduos passam a fronteira sem exibir qualquer documento; quem reside nas proximidades da fonteira pode cruzar para o outro país por determinados períodos de tempo, para visitas familiares ou em busca de água, por exemplo.”]

Na localidade de Santa Clara, no lado angolano da fronteira, circulam diariamente centenas de pessoas, sobretudo comerciantes e camionistas. As exportações angolanas para a Namíbia, via Santa Clara, correspondiam em 2002 a pouco mais de cinco milhões de USD. (GONÇALVES, 2010: 225)

Um conjunto de acordos assinados entre os dois Estados tem regulado a mobilidade: a resolução $n^{0}$ 3/07, sobre a isenção de vistos em passaportes diplomáticos, de serviço e ordinários dos cidadãos dos dois Estados e a resolução $n^{\circ}$ 4/07, aprovando o acordo sobre a designação e a abertura oficial dos postos de fronteira e pontos de entrada/postos de travessia, tendo em consideração os fusos horários em vigor nos dois países. Já a Resolução no 21/05, de 17 de agosto estabelece o Acordo Comercial, visando a promoção e o desenvolvimento do comércio e cooperação económica entre os dois Estados.

A isenção de vistos facilita a mobilidade entre a população dos dois países, tornando desnecessária a obrigatoriedade de solicitar autorização numa embaixada ou consulado. $\mathrm{Na}$ contemporaneidade, os principais procedimentos migratórios e alfandegários através do portão da fronteira sul de Angola (Santa Clara) e Norte da Namíbia (Oschikango) são: 
1) apresentação obrigatória aos agentes dos serviços de emigração de ambos os Estados, do passaporte ou do passe de travessia -- para as populações residentes ao longo da fronteira -- para a consequente deposição da chancela, ilustrando a passagem no posto fronteiriço;

2) preenchimento de um modelo referenciando o local de residência no país que visita e no país de origem;

3) registo da viatura e o pagamento da taxa de circulação ad-hoc mediante a apresentação da carta de condução da SADC, o título de propriedade e o livrete;

4) registo da mercadoria que transporta e respetiva tipologia.

Existem, porém, dinâmicas informais: para as populações residentes na linha da fronteira e conhecidas entre si, a apresentação às autoridades dos dois Estados do passe de travessia é suficiente para a permanência por horas no país vizinho, seja para visitas familiares ou, por exemplo, em busca de busca de água. Estas estratégias de simplificação de acesso entre os Estados fazem com que, para as comunidades locais, a fronteira em si não seja considerada como um obstáculo. Tal resulta do facto de a partilha dos espaços assimilada durante séculos continuar vigente para aceder aos recursos naturais devido à proeminência das leis migratórias de natureza regulatória, contrariamente às proibitivas. Assim, a multiplicidade étnica face à demarcação das fronteiras geográficas raramente constituirá um motivo suficiente para fazer eclodir conflitos, porque não existe uma pressão demográfica que implique desequilíbrio face aos recursos disponíveis.

No quadro das soberanias dos dois Estados, as travessias da fronteira assumiram um potencial significado de contextualização cultural permitindo a mobilidade para além de visitas familiares, de criadores de gado em busca de água e de agricultores à procura de terras férteis numa profundidade de até $30 \mathrm{~km}$ da linha de fronteira.

Figuras 02 e 03: Travessia Santa Clara (lado angolano) - Oshikango (lado namibiano)

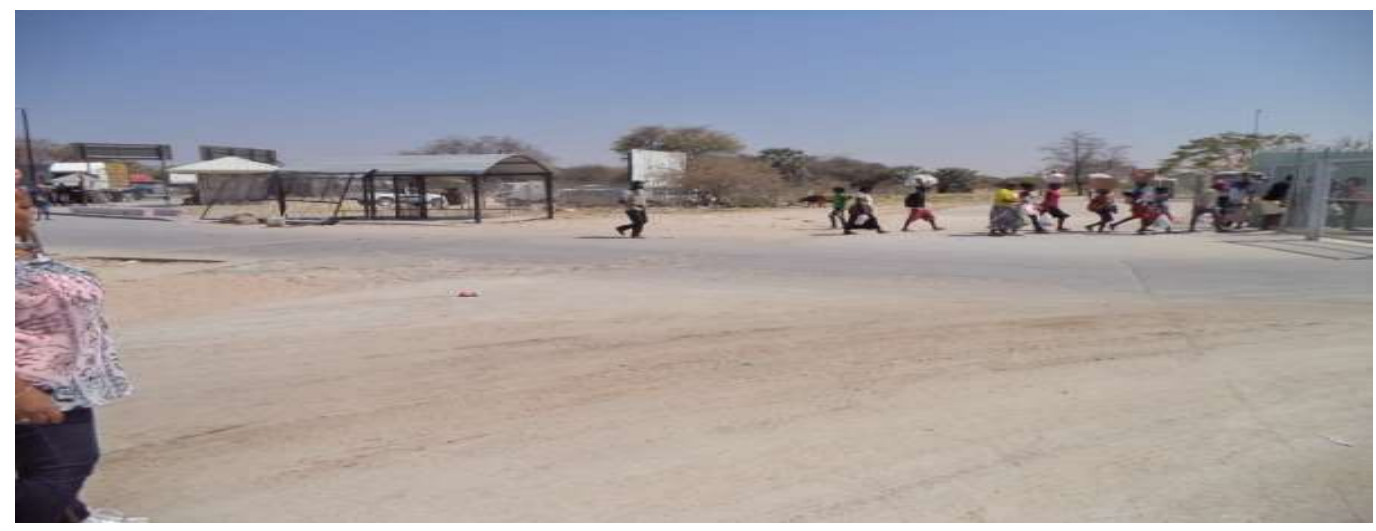




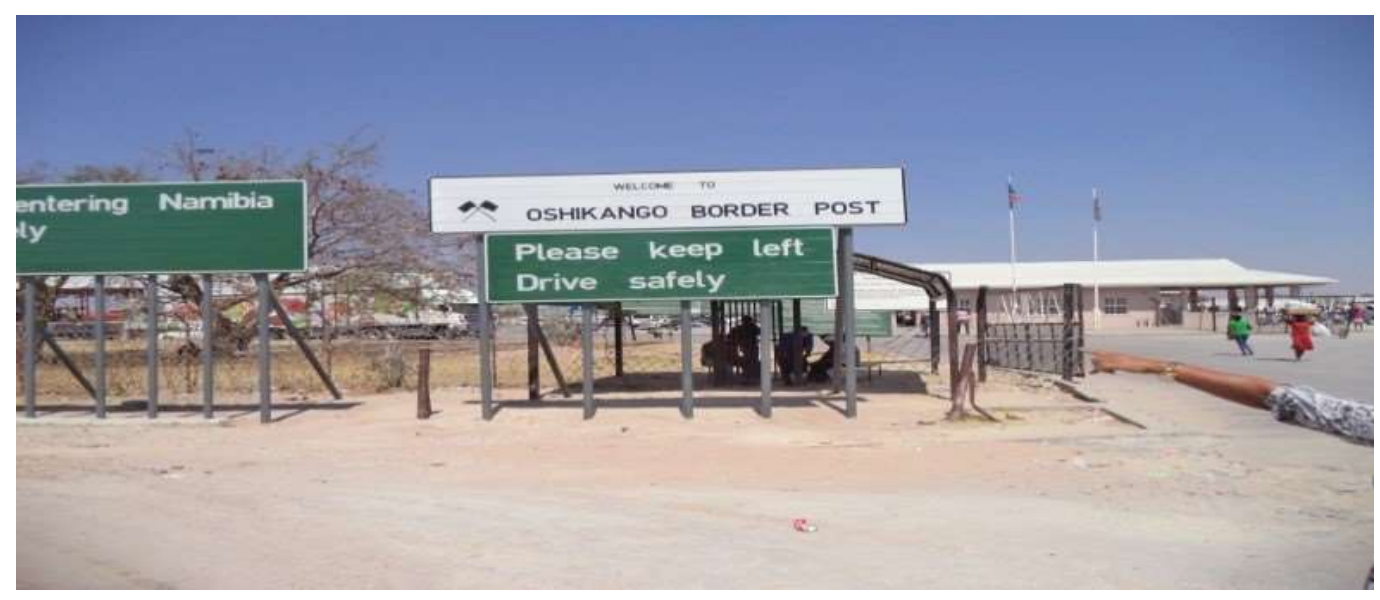

Fonte: Autora, 2014

Para além da dimensão do comércio bilateral, Santa Clara tem-se revelado um importante ponto "geoeconómico global [...] com capacidade para irradiar efeitos de desenvolvimento. Santa Clara está colada a Oshikango do lado namibiano, onde foi criada uma das zonas de processamento de exportação (EPZ). Esta proximidade 'cola' também Santa Clara ao mercado mundial e a um mercado interno dos melhores abastecidos de todo o continente, promovendo um movimento de importações essenciais para o comércio de todo o sudoeste de Angola e que garante a maior parte das receitas alfandegárias dessa mesma região [...]" (GONÇALVES, 2010: 225).

O crescimento populacional, segundo Gonçalves (2010) é mais,

acentuado nos municípios de Kwanhama e Ombadja onde se situam respetivamente as cidades de Ondjiva e Xangongo. Grande parte do aumento populacional, é produto de migração interna que dá a população local um perfil cada vez mais multiétnico. Ou seja, as duas etnias consideradas tradicionais na província acrescentam-se novas comunidades, principalmente dos planaltos do Huambo e Huila, que podem representar mais de $20 \%$ da população dos dois municípios referidos. (GONÇALVES, 2010: 247)

É na povoação de Santa Clara que a circulação fronteiriça legal regista números mais altos (Gonçalves, 2010; Udelsmann Rodrigues, 2014). É usada a distinção legal entre as "passagens não documentadas de fronteira e que alguns funcionários do sector classificam como migrações familiares", servindo para caracterizar os movimentos informais de entradas e saídas "com duração de alguns dias e estadia em casa de parentes ou em aldeias, de comunidades com afinidades de ambos os lados do arame farpado", onde pela ausência de documentação de muitos, torna difícil identificar a nacionalidade ou nacionalidades, no caso de possuir dupla. (GONÇALVES, 2010: 254) 
Outro aspeto importante, referenciado pelo mesmo autor, é a circulação registada em busca de água para consumo e pastagens.

A circulação do gado ao longo do mapa de poços tchimpacas e margem de rios, é com frequência perturbada pelas oscilações a que está submetida quase toda a província entre secas e inundações, na ausência de estruturas importantes de stocks coletivos de água e drenagem. (GONÇALVES, 2010: 254).

Constatou-se ainda que as populações, sobretudo as do Sul de Angola, estão num quase permanente movimento, quer à procura de melhores pastagens e água para o gado (que constitui a sua maior riqueza tangível e recurso económico), quer para realização de pequenos negócios ou para visitar familiares. Segundo Udelsmann Rodrigues (2014: 60) no período pósindependência registam-se situações novas, consequência das guerras civis que determinados Estados africanos viveram. Em Angola, vastos setores da população viram-se, de repente, confrontados com a necessidade de criar um novo modo de vida que lhes permitisse sobreviver longe das zonas de conflitos armados mais acentuados. Populações habituadas a diferentes "estratégias e dinâmicas" de vida tornam-se vítimas involuntárias de um conflito armado obrigando-se ao recurso ao "comércio transfronteiriço, facto para o qual as proximidades linguísticas e étnicas também contribuíram."

O complexo processo de comércio entre as fronteiras Sul de Angola (Cunene) e o Norte da Namíbia, implicou que inicialmente, nos primeiros anos da guerra civil angolana, a atividade comercial transfronteiriça tenha sido de carácter informal, envolvendo populações de ambos os lados, alterando a economia e as finanças, sobretudo de Angola - porque boa parte dos produtos não pagava nem taxas nem impostos - constituindo uma forma de sobrevivência de jovens da província do Cunene e de outras regiões do país, como alternativa à escassez de emprego. (UDELSMANN RODRIGUES, 2014)

Efetivamente, durante a guerra civil o comércio permaneceu ativo, envolvendo redes comerciais de produtos agrícolas tradicionais exportados para a Namíbia, não obstante as restrições impostas pelos conflitos.

Os angolanos mantiveram as suas lojas ao longo da fronteira, e o mesmo fizeram os namibianos, em áreas que foram crescendo rapidamente devido a demanda de Angola para Oshikango (DOBLER, 2009, apud UDELSMANN RODRIGUES, 2017:12).

A escassez de redes de abastecimento de mercadorias em Angola, durante e depois da guerra, as importações de bens da Namíbia bem como o isolamento do Sul do resto do país, permitiu o crescimento dos lucros do lado namibiano, e a intensificação da circulação 
comercial, sobretudo após o fim da guerra. Durante a guerra, a província do Cunene manteve mais contacto com a Namíbia do que com o resto do país.

A criação de uma área em expansão de intenso comércio, entre Santa Clara e Oshikango, na Namíbia, com a circulação do dólar, deu à população, sobretudo aos Cuanhamas, acrescidas razões para se envolverem em atividades transfronteiriças, estimulando o acesso a redes de saúde, escolas e outros serviços sociais existentes em Oshiwambo. O trajeto por via rodoviária efetua-se pela passagem pela fronteira Santa Clara/Oshikango, Calueque/Omahenene, Ruacana. Em Omahenene, apesar da guerra, a circulação manteve-se, regra geral, ativa, fruto dos laços étnicos e familiares (UDELSMANN RODRIGUES, 2017: 12).

De acordo com Dobler (2006, apud Udelsmann Rodrigues, 2014: 61), a paz e a estabilidade política em Angola e a melhoria das condições de vida das populações, reduziram as necessidades de importação de produtos da Namíbia, o que teve como consequência a redução da circulação através da fronteira. Contudo, as relações se manterão, ao nível de Estados e das populações, ativas e estáveis por muito tempo.

O número de cidadãos dos dois países a circular para ambos os lados da fronteira e o volume de negócios não estagnou, comercializando-se os mais diversos produtos desde bens alimentares a automóveis (não obstante, sentiu-se um decréscimo neste ramo com a proibição de entrada em Angola de automóveis com volante à direita). No quadro da recente crise económica, esta circulação foi ainda mais afetada.

Visando uma melhor gestão da fronteira sul de Angola, os governos de Angola e da Namíbia aprovaram, depois das independências, uma série de documentos reguladores das relações bilaterais:

- A Assembleia Nacional, em resolução no 21/05 de 17 de agosto, aprova o Acordo Comercial entre o Governo da República de Angola e o Governo da Namíbia (Diário da República, série $N^{\circ} 98$ de 21 de fevereiro de 2007), que visa a promoção e o desenvolvimento do comércio e cooperação económica entre a República de Angola e a República da Namíbia;

- Resolução $\mathrm{n}^{0}$ 2/07, de 21 de fevereiro, ao abrigo das disposições combinadas da alinea k) do artigo 88 e do $\mathrm{n}^{\mathrm{o}} 6$ do artigo 92 da Lei Constitucional, aprova o Protocolo de Cooperação no Domínio da Defesa entre o Governo da República de Angola e o Governo da República da Namíbia, de 6 de fevereiro de 2007, que contempla o na área militar, definição de políticas de defesa, instrução, troca de 
informações, missões de apoio à paz, desminagem, buscas, salvamentos e outras ações similares;

- Resolução no 3/07, que aprova o Acordo entre o Governo da República de Angola e o Governo da República da Namíbia, sobre a isenção do visto em passaportes diplomáticos, de serviço e ordinários dos cidadãos angolanos e namibianos que se desloquem para o respetivo Estado vizinho, estipulando: i) a isenção do visto de entrada para deslocações em missões privada, de serviço, trânsito ou de visita a familiares, mas apenas para uma estadia de 30 dias, renováveis por igual período; ii) a isenção de visto não impede cada um dos países de recusar ou proibir a entrada de cidadãos declarados perigosos para a ordem ou tranquilidade internas, ou considerados persona non grata;

- Resolução $n^{\circ}$ 4/07, que aprova o acordo entre o Governo da República de Angola e o governo da República da Namíbia, sobre a designação e a abertura oficial dos postos de fronteira e pontos de entrada/postos de travessia, tendo em consideração os fusos horários em vigor nos dois países. $\mathrm{O}$ acordo decreta que os cidadãos de ambos os países residentes ao longo da fronteira podem entrar reciprocamente no território de cada um até 60 quilómetros, sem necessidade de formalidades migratórias rígidas. Esta abertura permite que os cidadãos dos dois países possam não só pastar o seu gado em território vizinho, mas visitar familiares dos quais, por força do destino, estão separados pelo "arame" de delimitação fronteiriço.

Todos estes acordos são enquadrados pelo processo de integração regional na África Austral, a SADC. O quadro legislativo visa estabelecer relações de cooperação, no respeito pelo princípio da reciprocidade de vantagens, com salvaguarda da soberania, da independência e integridade territorial de cada país e conscientes dos direitos soberanos exercidos pelos Estados na defesa e proteção dos seus interesses vitais. As relações bilaterais regem-se em conformidade com o direito internacional, por um lado, e, por outro, na salvaguarda do entendimento mútuo, fruto dos laços forjados durante os anos de luta pela independência de Angola e Namíbia.

Segundo o relatório Perfil e Rotas da imigração ilegal em Angola (MINISTÉRIO DO INTERIOR, SERVIÇOS DE EMIGRAÇÃO ESTRANGEIRA DA REPÚBLICA DE ANGOLA, 2011), “O protocolo que regula a facilitação de movimentos de pessoas, assinado em 2005, no âmbito da Comunidade de Desenvolvimento da África Austral (SADC), estabelece o enquadramento necessário para a entrada e permanência, sem necessidade de visto, dos cidadãos dos países signatários, e para facilitação da atividade profissional e desenvolvimento 
de negócios por cidadãos desses Estados. O protocolo tem como signatários Angola, Botsuana, República Democrática do Congo, Lesoto, Malawi, Maurícias, Moçambique, Namíbia, África do Sul, Suazilândia, Tanzânia, Zâmbia e Zimbabué". Este protocolo é um "instrumento facilitador do combate a emigração", mesmo que nem sempre se revele eficaz, tanto na prevenção como na sua execução. A sua eficácia está estritamente dependente da criação de "estruturas de cooperação mais fortes entre Estados, concernentes sobretudo a prevenção e vigilância dos fenómenos que a imigração ilegal diz respeito", e melhoria na formação dos integrantes do Serviço de Migração e Estrangeiros, Policia Nacional e as Forças Armadas, entidades responsáveis pelo combate à imigração ilegal (MINISTÉRIO DO INTERIOR, SERVIÇOS DE EMIGRAÇÃO ESTRANGEIRA DA REPÚBLICA DE ANGOLA, 2011: 22).

Com a produção e implementação destas ferramentas reguladoras, as populações dos dois Estados têm ao seu dispor os instrumentos básicos para uma melhor gestão das dinâmicas transfronteiriças, tanto em termos de mobilidade populacional como económica. Os movimentos populacionais são constantes na província do Cunene, com grande incidência no município do Cuanhama (UDELSMANN RODRIGUES, 2010) sendo que a zona de processamento de exportação $(\mathrm{EPZ})$ de Oshikango tem a sua vida totalmente ligada à movimentação via Santa Clara, quer segundo normas formais ou informais.

O relatório Perfil e Rotas da imigração ilegal em Angola refere a zona de fronteira como lugar aproveitado para passagem de imigrantes ilegais que entram em Angola, sendo que os métodos utilizados pelas redes de auxílio ilegal e tráfico de pessoas evoluíram e são hoje mais difíceis de detetar,

[...] As tipologias da imigração ilegal em Angola, distinguindo-se os emigrantes ligados a redes de auxílio à imigração ilegal e tráfico de pessoas, daqueles que emigram de modo irregular de modo isolado, e daqueles que excedem o prazo de autorização de permanência previsto na sua documentação legal. (MINISTÉRIO DO INTERIOR, SERVIÇOS DE EMIGRAÇÃO ESTRANGEIRA DA REPÚBLICA DE ANGOLA, 2011: 3)

O relatório aponta um aspeto em comum em alguns grupos, sendo a "busca de melhores oportunidades" (MINISTÉRIO DO INTERIOR, SERVIÇOS DE EMIGRAÇÃO ESTRANGEIRA DA REPÚBLICA DE ANGOLA, 2011: 4), onde nem todos o fazem de modo regular, ou seja, há quem atue à margem da lei. O desemprego e miséria, a instabilidade política, a internacionalização da produção, a escassez económica e a globalização, são algumas das 
As dinâmicas formais/informais e modus operandi da mobilidade da população fronteiriça do sul de Angola Sónia Cristina Cardoso dos Santos Silva

motivações para a entrada de imigrantes em Angola. (Ministério do Interior, Serviços de Emigração Estrangeira da República de Angola, 2011: 6) $)^{31}$

Nas atividades diárias de fiscalização da mobilidade transfronteiriça, as autoridades migratórias registam quatro tipos de violações: "fraude documental, falta de documentos, violações da fronteira, e permanência ilegal" (MINISTÉRIO DO INTERIOR, SERVIÇOS DE EMIGRAÇÃO ESTRANGEIRA DA REPÚBLICA DE ANGOLA, 2011: 11). Entre 2000 e 2010, as nacionalidades com maior número de imigrantes - alguns alvos de processos de expulsão do território angolano - foram a República Democrática do Congo; a Guiné Conacri, a China, o Mali e a Nigéria, num total de 5361 cidadãos (MINISTÉRIO DO INTERIOR, SERVIÇOS DE EMIGRAÇÃO ESTRANGEIRA DA REPÚBLICA DE ANGOLA, 2011: 12).

Segundo o mesmo relatório, existem várias rotas de acesso ao território angolano: “a Rota do Cunene, que segue a via áerea e terrestre, afirmando-se como uma alternativa à rota do Zaire, com redes de auxílio à imigração ilegal a optarem por utilizar vários pontos menos vigiados na extensa fronteira com a Namíbia. Trata-se de imigrantes ilegais provenientes do Congo e da República do Congo, em especial. A passagem é feita por via terrestre, por via pedestre ou através dos transportes públicos" (MINISTÉRIO DO INTERIOR, SERVIÇOS DE EMIGRAÇÃO ESTRANGEIRA DA REPÚBLICA DE ANGOLA, 2011: 20).

Figura 04: Vedação do lado de Angola, erigida em 2013

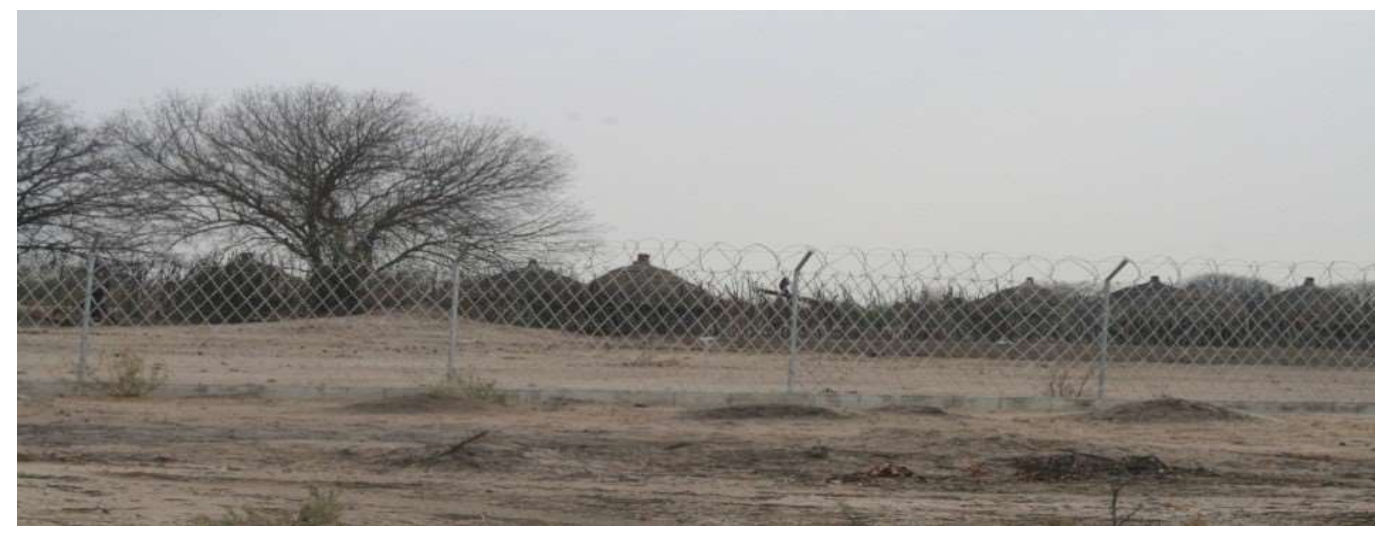

Fonte: Autora, 2015.

\footnotetext{
${ }^{31}$ De acordo com o Banco Mundial, em toda a área da Comunidade de Desenvolvimento da África Austral (África do Sul, Angola, Botsuana, Lesoto, Malawi, Maurícias, Moçambique, Namíbia, República Democrática do Congo, Seychelles, Suazilândia, Tanzânia, Zâmbia e Zimbabwe), a imigração ilegal "é claramente dominada pelos homens", em especial adultos ou jovens adultos. No entanto, verifica-se uma tendência crescente, a nível global, para uma amenização da imigração ilegal, e na área geográfica da SADC "as mulheres concentram-se em especial em atividades informais junto a fronteira". Os homens concentram-se nas minas de diamantes, bem como noutras explorações mineiras no Leste do país, muitas vezes em regimes de trabalho informal ou mesmo em regime de semiescravidão. Mulheres e crianças recorrem ao trabalho informal em Luanda, mas registam-se igualmente práticas de prostituição nas regiões mineiras. As crianças são frequentemente utilizadas para transporte clandestino de divisas entre Angola e Namíbia. Cfr. Relatório Perfil e Rotas da imigração ilegal em Angola (Ministério do Interior, Serviços de Emigração Estrangeira da República de Angola, 2011: 10).
} 
Entretanto, "para um melhor controlo sobre a fronteira sul de Angola, as autoridades angolanas erigiram, em 2013, uma vedação no perímetro da fronteira entre Angola e a Namíbia, num raio de 30 quilómetros de Santa Clara (do marco 18 ao 20), com o objetivo de combater a violação da fronteira, a imigração ilegal, o contrabando e a fuga ao fisco". A localização neste sector justifica-se por constituir uma zona de comércio fronteiriço formal. Apesar desta medida, em 2015 uma parte da vedação foi destruída, aumentando as possibilidades de contrabando de mercadorias e de tráfico de droga, sobretudo pela existência de aglomerados populacionais próximos da fronteira. (resultado da observação no terreno pela candidata e de explicações locais como, por exemplo, do entrevistado 16, sexo masculino, 34 anos, polícia de guarda fronteira e criador de gado)

De acordo com as informações prestadas pelos serviços de guarda fronteira, estava previsto para dezembro de 2017 o início da construção da vedação, que deveria estar concluída em 2018.

No quadro das negociações encetadas no âmbito da SADC, visando a melhoria e aumento da mobilidade de pessoas e bens entre os respetivos países integrantes, existe ainda um pré-acordo entre a Namíbia e Angola para a construção de um caminho-de-ferro. Neste contexto, o entrevistado 1 (sexo masculino, 55 anos, soba e criador de gado), refere que a "Namíbia já construiu a linha até Oshikango, cidade que faz fronteira com o município de Namacunde, povoação de Santa Clara, cabendo a Angola dar continuidade ao projeto pelo interior do território angolano, com vista a uma mais fluida mobilidade e cooperação entre os dois países".

Figuras 05 e 06: Rede destruída (Angola)

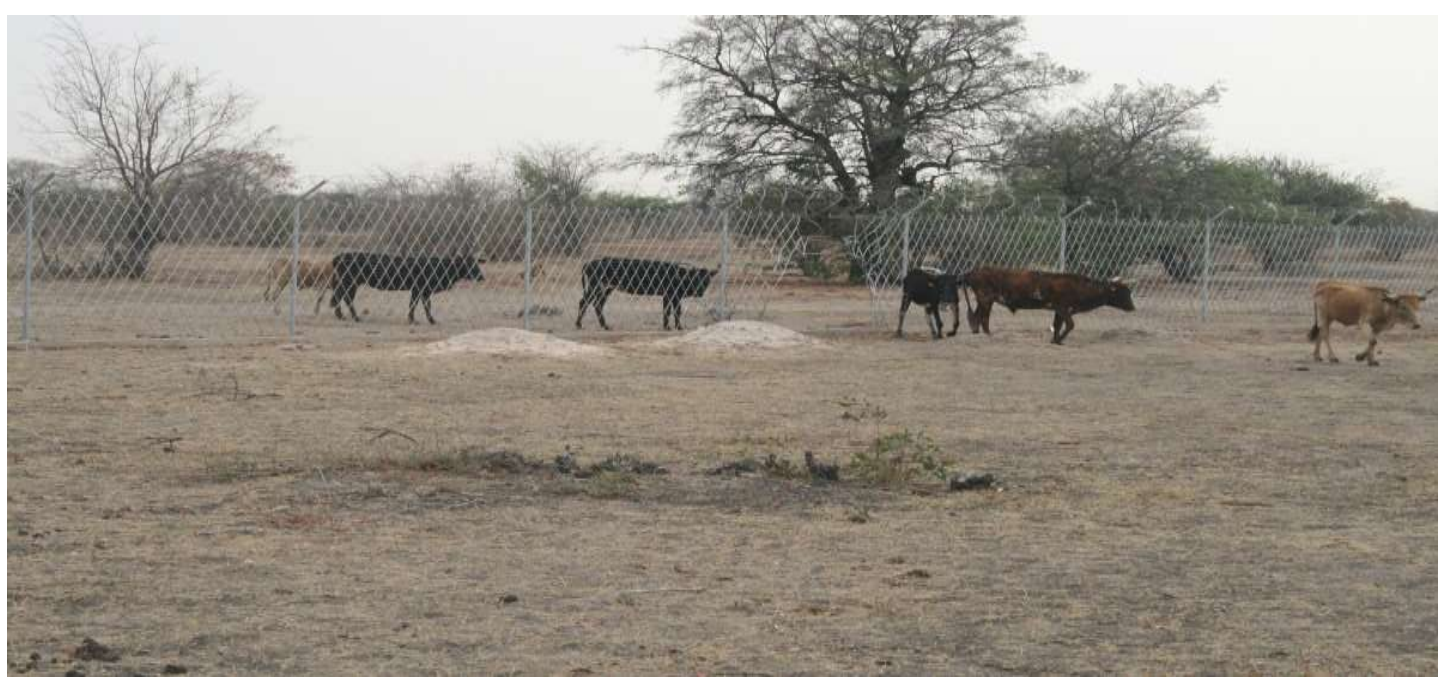




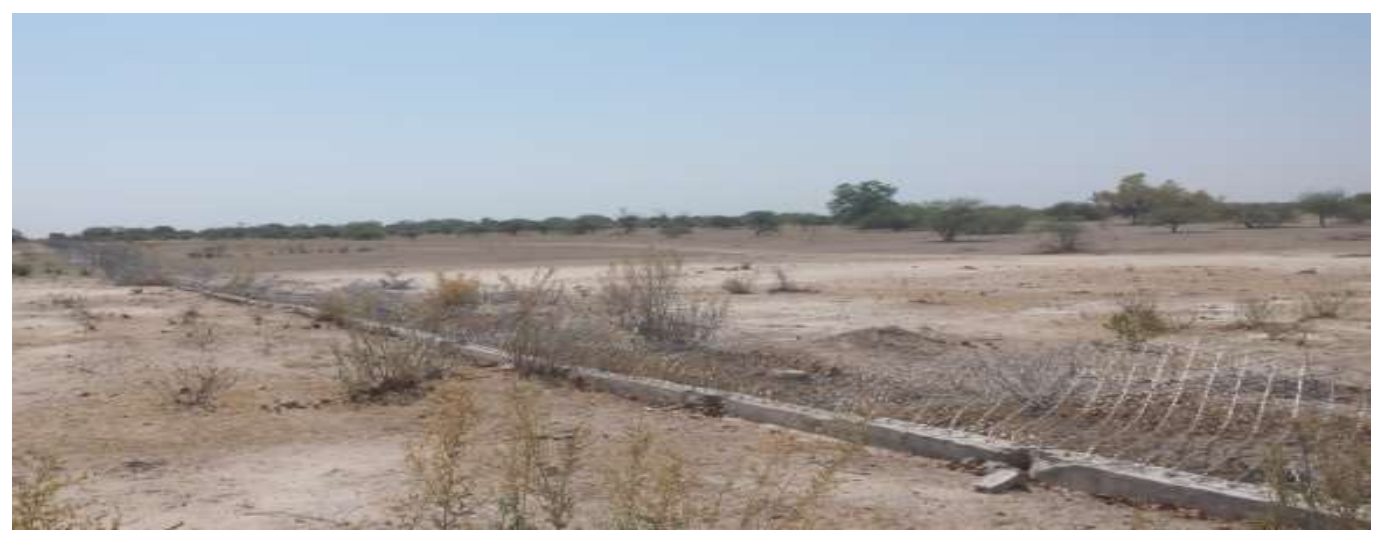

Fonte: Autora, 2015.

Em termos de circulação de capitais, foi assinado a 22 de setembro de 2014 o Acordo de Conversão Monetária entre o Banco Nacional de Angola (BNA) e o Banco da Namíbia (BON) que entrou em vigor a 18 de junho de 2015, visando, segundo a ANGOP (21 de dezembro de 2015), o "reforço e a simplificação das transações comerciais entre as populações residentes nas zonas fronteiriças de Santa Clara (Angola) e Oshikango (Namíbia)".Tratou-se de um instrumento que em muito facilitou a mobilidade das populações residentes e/ou de passagem entre ambos os lados da fronteira. No entanto, a 3 de dezembro de 2015, o acordo foi temporariamente suspenso em decorrência da "elevada massa monetária" (ECONOMIA, 3 de dezembro de 2015). Ou seja, os dois bancos protelaram-no até que fossem "criadas as condições para a materialização de um novo modelo de implementação do compromisso". A 21 de dezembro de 2015, o acordo de conversão monetária foi, segundo a Angola Consulte (13 de dezembro de 2019) retomado para permitir que, em caso de doença, negócio ou mesmo por questões ligadas a estudos, os indivíduos disponham de dinheiro do país visitado em quantias que lhes possibilitem pagar as despesas imediatas, sem serem necessárias transações em moedas terceiras.

O protocolo comercial da SADC ${ }^{32}$ foi assinado em Maseru- Lesoto, em agosto de 1996, sendo um instrumento legal que regula as relações comerciais entre os Países Membros

\footnotetext{
32 A SADC - Comunidade de Desenvolvimento da África Austral - foi criada em 1992, a partir da transformação da SADCC (Southern Africa Development Co-ordination Conference ou Conferência de Coordenação para o Desenvolvimento da África Austral), criada em 1980 por nove dos estados membros. Esta transformação ocorreu em 17 de agosto de 1992 em Windhoek, Namíbia, motivada pelo fim do regime de apartheid na África do Sul. A SADC engloba 15 países do Sul da África: África do Sul, Angola, Botsuana, República Democrática do Congo, Lesoto, Madagáscar, Malawi, Maurícias, Moçambique, Namíbia, Suazilândia, Tanzânia, Zâmbia, Zimbabué e Seicheles. Esta organização intergovernamental visa a integração sócio-económica e a cooperação política dos países da África Austral.

Dos 15 Estados membros, 12 já integram a zona de comércio livre. As exceções são Angola, a República Democráica do Congo e as Seychelles, sendo que este último já formulou o pedido de adesão. Cf. https://pt.wikipedia.org/wiki/Comunidade_de_Desenvolvimento_da_\%C3\%81frica_Austral
} 
Subscritores da SADC (Botsuana, Lesoto, Malawi, Maurícias, Moçambique, Namíbia, África do Sul, Suazilândia, Seychelles, Tanzânia, Zâmbia e Zimbabué. Moçambique ratificou através da resolução nº44/99, publicado no DR n ${ }^{0}$ 52, de 29 de dezembro de 1999, I Série. Permite o incremento das actividades comerciais, livre circulação de bens, isenção de tarifas entre outros benefícios

Na sequência dos acordos que dinamizam a livre circulação de pessoas, Angola assinou em março de 2004 o Protocolo de Livre Comércio da SADC ${ }^{33}$, não tendo materializado a adesão plena, tendo priorizado na sua agenda aspetos como a modernização do tecido produtivo interno, a reestruturação da economia, a reabilitação e modernização das infraestruturas de transporte, eletricidade, comunicações, tendo como objetivo a indução de maiores taxas de crescimento económico e eficiência produtiva interna. ${ }^{34}$ (O PAÍS, 2018)

A 21 de março de 2018, Angola foi um dos 44 países que assinaram, em Kigali, Ruanda, o tratado que cria a Zona de Livre Comércio do Continente Africano. Este tratado pretende materializar uma das aspirações da União Africana: a integração económica do continente, como base em ideias pan-africanistas. Entretanto, importa recordar que nem todos os 55 Estados membros da UA assinaram o tratado, com maior destaque para Nigéria e África do Sul, as maiores economias do continente, bem como cinco outros países que integram a SADC: Namíbia, Lesoto, Zâmbia, Botsuana e a Tanzânia. As ausências destes países condicionam o sucesso futuro da iniciativa, sendo que influenciam diretamente os benefícios que Angola pode vir, a prazo, a retirar da iniciativa.

A liberdade de circulação entre os países africanos é uma aspiração já antiga, ainda no quadro da OUA, e que a União Africana tem procurado operacionalizar. De acordo com o índice de abertura de vistos do Banco Africano de Desenvolvimento (BAD), apenas 13 países africanos garantiam liberdade de acesso a cidadão africanos ${ }^{35}$. Este índice permite medir o grau de abertura relativamente à circulação de pessoas, examinando os requisitos de entrada a cidadãos africanos. De acordo com o Protocolo ao Tratado que Estabelece a Comunidade Económica Africana em Matéria de Livre Circulação de Pessoas, Direito de Residência e

\footnotetext{
https:/www.mic.gov.mz/por/Comercio-Externo/Acordos-Bilaterais/PROTOCOLO-SOBRE-TROCASCOMERCIAIS-DA-SADC

33 O País, 27 de março de 2018, disponível em https://opais.co.ao/index.php/2018/03/27/a-adesao-de-angola-azona-de-livre-comercio/

34 Idem

35 Ibidem
} 
As dinâmicas formais/informais e modus operandi da mobilidade da população fronteiriça do sul de Angola Sónia Cristina Cardoso dos Santos Silva

Direito de Estabelecimento ${ }^{36}$, adotado em março de 2018, prevê, entre outras disposições, a abolição da necessidade de visto de entrada para cidadãos africanos (Art. $6^{\circ}$ ) e a adoção de um passaporte africano $\left(\right.$ Art. $\left.10^{\circ}\right)$, concebido e com especificações à escala continental, respeitando normas nacionais e internacionais. Angola é um dos 32 países que já assinou o Protocolo. Ainda não é o caso da Namíbia que, no entanto, prevê a abolição de vistos para cidadãos africanos.

Fora das disposições formais, as populações de ambos os lados da fronteira sul de Angola, arranjaram mecanismos de sobrevivência informais que lhe permitissem a mobilidade entre os dois Estados. Segundo Udelsmann Rodrigues (2017: 4), a intensificação da circulação transfronteiriça, permitido pela circulação rodoviária, ativou fortes relações familiares transfronteiriças e redes tradicionais baseadas em contactos entre Kwanhamas angolanos e namibianos. Estas relações incorporam a identidade kwanhama desses povos fronteiriços, numa relação simultânea de separação e proximidade, que Udelsmannn Rodrigues designa por identidade cruzada na fronteira. A gestão desta proximidade/separação integra igualmente ferramentas de gestão dos recursos transfronteiriços, desde logo a água, a terra e o gado.

Aprofundando a questão da mobilidade e o respetivo controlo, a existência das portinholas, por exemplo, tem por objetivo atender as necessidades das populações residentes ao longo da fronteira, facilitando a mobilidade e consequentemente o comércio naquele lugar. O entrevistado 17 (sexo masculino, 50 anos, polícia de guarda fronteira) refere como mecanismos de controlo e de ajuda as populações dos dois lados o funcionamento dos portões de acesso as populações:

Para além do portão principal de Santa Clara, que abre às 8 horas da manhã e fecha às 18 horas, também se regista o mesmo fluxo ou movimento no Emaenene (marco 5), que dá acesso a povoação de Kalueque, com o mesmo tipo de serviços migratórios e alfandegários. Existem ainda outros portões com menor fluxo de populações, no marco 9, que dá acesso ao Xangongo, e no marco 12, no Okalongo. Estes dois portões servem quase exclusivamente as populações residentes. Por último, o portão ou entrada do Ruacaná (marco 1) no município do Curoca, que também é pouco utilizado, dada a distância das localidades. Todos estes portões, com menor ou maior circulação de pessoas, têm o mesmo sistema de serviços alfandegários e de controlo de pessoas (residentes ou turistas) e mercadorias.

Já relativamente às relações entre as respetivas populações, incluindo os fluxos comerciais transfronteiriços, de acordo com as entrevistas, no período pós-independência, “os

\footnotetext{
${ }^{36}$ Disponível em https://au.int/en/treaties/protocol-treaty-establishing-african-economic-community-relating-freemovement-persons, consultado a 27 de julho, O País, 27 de março de 2018, disponível em https://opais.co.ao/index.php/2018/03/27/a-adesao-de-angola-a-zona-de-livre-comercio/
} 
As dinâmicas formais/informais e modus operandi da mobilidade da população fronteiriça do sul de Angola Sónia Cristina Cardoso dos Santos Silva

angolanos deslocam-se à Namíbia para adquirir produtos diversos (açúcar, sal, cerveja, arroz, etc.), que depois revendiam em pequenos espaços comerciais ao longo do marco 16. Nesta zona, o território angolano não alberga qualquer tipo de indústria e tem escassez de serviços, pelo que os indivíduos procuram emprego, assistência médica e medicamentosa, ensino e produtos básicos na Namíbia. Os namibianos, por seu lado, procuram em Angola emprego e tratamentos tradicionais, bem como mercados para a venda dos seus produtos" (entrevistado 9, sexo masculino, 43 anos, comerciante no marco 16, lado angolano)

Segundo uma entrevista feita a uma Polícia de Guarda Fronteira namibiana, sobre a mobilidade atual nas portinholas existentes entre o território angolano e namibiano revela que:

Os angolanos têm vindo à Namíbia passando pelas portinholas, como podem observar, sem nenhum impedimento, com a finalidade de busca do líquido (água), aproveitam a fazer suas consultas médicas, e assistem a missa ao longo desta fronteira na parte namibiana, concretamente na área de Odibo. Existem trocas comerciais em ambas as partes. Os namibianos têm passado para o lado angolano, com fim de visitar seus familiares (e vice-versa), pastos de gado suas fazendas e também os curandeiros ou tratamentos tradicionais ${ }^{37}$ (entrevistado 15, 38 anos, PGF da Namíbia).

Perante a 'informalidade' no cruzamento da fronteira, evitando cumprir as disposições legais em vigor, "as autoridades angolanas decidiram, em 2012, aperfeiçoar os mecanismos de controlo e vigilância fronteiriça do marco 18 (na região da Ombadja) ao marco 20 (Okatali), no município de Namacunde. Paralelamente reforçou-se a formação do pessoal, com o propósito de se exercer um maior controlo de pessoas e bens, procurando combater o contrabando e fuga ao fisco" (entrevistada 16, sexo masculino, 34 anos, PGF).

“A rede colocada do lado angolano tem uma extensão de 40 quilómetros, 20 para cada lado das instalações aduaneiras. De lembrar que a rede não delimita a fronteira, razão pela qual foi erguida a 25 metros do limite fronteiriço do lado namibiano" (entrevistada 16, sexo masculino, 34 anos, PGF)..

Do lado da Namíbia encontramos uma marcação com arame. Trata-se de uma estratégia da polícia de fronteira namibiana, denominada de "pista". Quem viole a fronteira não consegue evitar deixar pegadas, o que alerta as autoridades, cita a mesma fonte.

\footnotetext{
${ }^{37}$ A resposta original foi dada em língua Cuanhama: Ova Angola ohaveia moshilongo shetu shanamibia, tavapitile pomivelo ilo pemiito diapu adimonika movelo we ngamba ngashi tashitalika oshiwetikwe kushe umwe. Ohaveya moshilongo shetu luampu tava kongo omeva, vo tava kongo oukolele moipangelo, vo tava heogalo mogeleka inha ya dibo. Openaa eudafano lokudengapo emumbwe dovashiwana vo Angola na Namibia oshiapu momaladifo moinima. Ova Namibia vahapu ohavayi mohangola tavakatalelapo e familia davo no okulifa oimuna no mapiavo ine oukolele me dudu (tradução do Cuanhama para português pelo intérprete).
} 
A mobilidade populacional não é recente, muito menos exclusiva do período pósindependência, seja em contexto de guerra civil, no quadro do conflito entre Angola e a África do Sul ou em época de paz. Antes do conflito, segundo Visentin (2013: 3), a mobilidade/migração já "fazia parte da quotidianidade" dos angolanos que se deslocavam frequentemente para o outro lado da fronteira, quer para o Sudoeste Africano (Namíbia), para a África do Sul, para a Zâmbia e os dois Congos. As fronteiras, mais do que nunca, são hoje reconhecidas como lugares de contacto mútuo, de aproximação e de mercado fértil.

Esta ideia é igualmente subscrita por Oliveira (2010), quando analisa o conceito de fronteira na perspetiva do direito internacional:

"como uma zona de contacto e de relações de contiguidade entre Estados, a fronteira é um lugar de relações, um regime de relações entre dois Estados dentro de um território misto, resultante da reunião das suas zonas periféricas territoriais respetivas." (OLIVEIRA, 2010: 14)

$\mathrm{O}$ estabelecimento da fronteira, historicamente, teve impactos locais complexos e variados. “[...] não só criou espaços, como influenciou as economias locais, a comunicação e circulação dentro da área de fronteira e o sentimento de pertença entre as populações de ambos os lados da fronteira, introduzindo novas dinâmicas na identidade fronteiriça e gestão dos recursos.”(UDELSMANN RODRIGUES, 2017: 6)

As trocas linguísticas influenciaram a formação da identidade, dos dois lados da fronteira, baseada em laços regionais e na identidade étnica Cuanhama. Surgem diferenciações e alterações linguísticas; os Cuanhama angolanos que residem mais longe da fronteira falam português como língua oficial e de trabalho, enquanto os que se estabeleceram na fronteira e os mais jovens, que estudaram e/ou que vivem na Namíbia, falam Inglês e Afrikaans.

Quanto ao Oshiwambo, apesar de não ser usado pelos Cuanhamas em Angola, subsiste em círculos familiares ou comunitários imediatos, devido a influência dos laços advindos das constantes permanências no território namibiano.

$\mathrm{O}$ estabelecimento da fronteira sul gerou alterações na gestão dos recursos pelas populações dos dois Estados, Angola e Namíbia, e teve igualmente impactos profundos a nível social, político e económico, com desenvolvimentos diferentes nos dois lados da fronteira.

Os percursos dos processos de construção de identidades nacionais após as independências fizeram emergir diferenças entre os Cuanhamas dos dois lados. Com efeito, os Ovambo namibianos têm acesso a certas vantagens, são vistos como mais organizados. Já os angolanos, mesmo sendo Ovambos, são olhados com algum ceticismo. A melhor disponibilidade de serviços (como, por exemplo, as lojas localizadas em Oshikango, na 
Namíbia), concedeu-1hes um maior grau de organização, tornando-os, na pós-independência, cada vez mais distintos (UDELSMANN RODRIGUES, 2017: 5, 11).

De acordo com Udelsmann Rodrigues, "as fronteiras angolanas, são sobretudo porosas e fluidas. Há áreas sociais, culturais e de trocas intensas nas zonas de fronteira que não se regem pelas linhas estabelecidas nos mapas (2011). Durante e após o final da guerra, a circulação na região depende de intensas trocas comerciais (UDELSMANN RODRIGUES, 2017:6) mas também da reconfiguração de redes de circulação relacionas com os recursos naturais.

\section{Reflexão Final}

Pode-se concluir que em relação às estratégias das comunidades locais, a fronteira em si não é considerada um obstáculo. A questão é a forma como os povos fronteiriços dos dois países, habituados a partilhar o mesmo espaço, têm gerido de modo próprio, nos períodos précolonial, colonial e de independência os recursos naturais.

A fronteira passa a configurar um problema quando se juntam outras variáveis, como: i) dificuldade do acesso aos recursos (i) densidade demográfica; (ii) disposição de recursos naturais, essencialmente minerais de interesse imediato à industrialização ocidental; (iii) leis migratórias proibitivas em vez de regulatórias; (iv) pressão externa do Ocidente sobre os territórios africanos potencialmente ricos.

No que se refere a Angola e Namíbia, as leis migratórias são sobretudo regulatórias. A multiplicidade étnica não constitui motivo de conflito como tal, e nem existe uma pressão demográfica que implique desequilíbrio face aos recursos disponíveis.

Em suma, a mobilidade populacional na fronteira sul de Angola alterou-se nos três períodos históricos identificados. Numa fase pré-colonial, seria marcada por mais liberdade de movimentos, que passa a ser controlada com a instauração do aparelho estatal colonial.

Com a colonização, os recursos naturais $\mathrm{e}$ as formas de desenvolvimento $\mathrm{e}$ relacionamento social passaram a ser controladas pelas potências colonizadoras. $\mathrm{O}$ colonialismo impôs em África padrões ocidentais (leis, normas, códigos) de gestão dos espaços geopolíticos e dos recursos naturais, e reduziu a capacidade de mobilidade das populações. Com as independências, os novos Estados passaram a gerir, de forma moldada pelos padrões herdados do período colonial, os seus próprios recursos. Contudo, a guerra impôs a Angola e à Namíbia importantes condicionamentos à gestão transfronteiriça de recursos, enquanto o pós- 
As dinâmicas formais/informais e modus operandi da mobilidade da população fronteiriça do sul de Angola Sónia Cristina Cardoso dos Santos Silva

guerra acelerou a reorganização da circulação e da mobilidade e introduziu novas dinâmicas locais.

Após as independências, a fronteira sul conhece um período de maior controlo, fruto de circunstâncias muito específicas: o desenrolar do conflito interno angolano e sobretudo o confronto com a África do Sul em torno da independência da Namíbia impõe restrições à circulação da população. Depois das independências, a mobilidade continua a ser controlada pelos Estados, mas desenvolvem-se novos mecanismos informais de controlo e passagem criados pelas populações. As trocas linguísticas influenciaram a formação da identidade, dos dois lados da fronteira, baseada em laços regionais e na identidade étnica Cuanhama. Surgem diferenciações e alterações linguísticas.

Com a independência da Namíbia 21 março de 1990 e de Angola em 11 de novembro 1975 e consequente fim da guerra civil em Angola em 2002, a fronteira volta a ser mais porosa, permitindo uma maior mobilidade, formal e informal, bem como o desenvolvimento de relações transfronteiriças, a nível individual, comunitário e económico.

As opções estratégicas dos dois Estados no âmbito das políticas e relações internacionais salvaguardaram as dinâmicas socioculturais das populações. Ou seja, a mobilidade de pessoas de um lado para o outro da fronteira Angola-Namíbia é determinada por relações étnica e transnacionais seculares devidas a situações de ordem económica, cultural ou familiar. Persistem rotas migratórias, trocas comerciais e fidelidades políticas entre povos limítrofes as quais foram continuamente sujeitas à regulação.

Figura 07: Polícias de Guarda Fronteira Namibiana e Angolana, no controle da mobilidade fronteiriça nas portinholas (lugar de passagem de pessoas e gado), localidade de Okatale, Município de Namacunde. na província do Cunene.

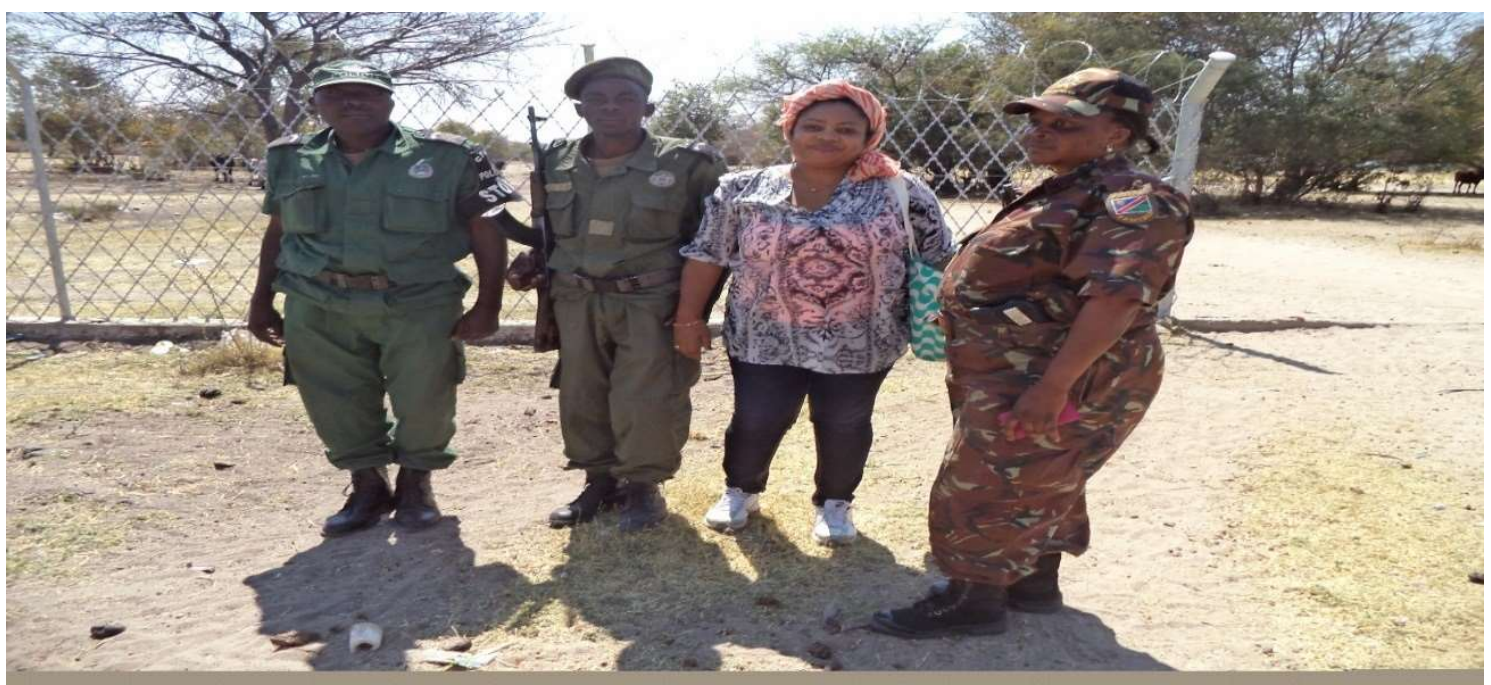

Fonte: Autora, 2015. 


\section{Referências}

APARÍCIO, Alexandra. "O último reino independente de Angola e a fixação da fronteira sul 1910-1926”, In: Maria Emilia Madeira Santos (dir.), África e a instalação do sistema colonial - c.1885 - c.1930: III reunião internacional de história de África: actas, Lisboa, Centro de estudos de História e cartografia antiga, 2000.

AUGUSTONI, Prisca e Viana, Anderson Luiz. "A identidade do sujeito na fronteira do póscolonialismo em Angola", In: IPOTESI, 14 (2), 2010, p. 189-205. Disponível em: http://www.ufjf.br/revistaipotesi/files/2011/04/16-A-identidade-do-sujeito-na-fronteira-dop\%C3\%B3s-colonialismo-em-Angola.pdf. Consultado em 14.02.2017.

AMARAL, Ilídio do. "Fronteiras internacionais africanas", em Separata de "As fronteiras de África”, Lisboa, Comissão Nacional para as Comemorações dos Descobrimentos Portugueses, 1997.

BARBIERI, Alisson F. et al. "Climate change and population migration in Brazil's Northeast: scenarios for 2025-2050”, In: Population and Environment. 31(5), 2010, p. 344-370. Doi: 10.1007/s11111-010-0105-1.

BOLLIG, Michael e Jan Bart Gewald (eds.). People, Cattle and Land: Transformations of a Pastoral Society in Southwesten Africa. Rüdiger Köppe, 2009.

DÖPCKE, Wolfgang. "A vida longa das linhas retas: cinco mitos sobre as fronteiras na África Negra”. In: Revista Brasileira de Política Internacional. 42(1), 1999, p. 77-109. Doi: 10.1590/S0034-73291999000100004.

DUARTE, Rosália. "Pesquisa qualitativa: reflexões sobre o trabalho de campo". In: Cadernos de Pesquisa. 115, 2002 p. 139-154. Doi: 10.1590/S0100-15742002000100005.

ESTERMANN, Carlos. Etnografia do sudoeste africano - Os povos Não - bantos e o grupo étnico Ambó. Vol. 1, Lisboa, Junta de Investigações do Ultramar, 1956.

ESTERMANN, Carlos. O Rio Cunene. Luanda, Instituto de Investigação Científica de Angola, 1976.

ESTERMANN, Carlos. Etnografia de Angola (sudoeste e centro): coletânea de artigos dispersos. Vol. 2, Lisboa, Instituto de Investigação Científica Tropical, 1983.

FARAH, Nuruddin. “A maldição das fronteiras coloniais em África”. In: AfroArticles. S/a. Disponível em: http://www.afroarticles.com/. S/d.

FERREIRA, Iremar Antonio. “Alerta: falta de água potável pode comprometer a vida de bilhões de pessoas". In: Sem Fronteiras No Madeira. 2013. http://semfronteirasnomadeira.blogspot.com/2013/04/alerta-falta-de-agua-potavel-pode.html. Consultado em 15.11.2014.

GONÇALVES, José Manuel. "Dinâmicas sociais na estruturação geoeconómica do baixo Kunene, (novas e velhas transumâncias)". In: Fernando Florêncio (ed.), Vozes do universo rural: reescrevendo o Estado em África. Lisboa, Centro de Estudos Africanos, 2010. https://books.openedition.org/cei/203

KEESE, Alexander. "Developmentalist attitudes and old habits: Portuguese labour policies, South African rivalry, and flight in, 1945-1974". In: Journal of Southern African Studies. 41(2), 2015, p. 237-253. 
As dinâmicas formais/informais e modus operandi da mobilidade da população fronteiriça do sul de Angola Sónia Cristina Cardoso dos Santos Silva

LAMPHEAr, John. The Traditional History of the Jie of Uganda. Oxford, Clarendon Press Oxford Studies in African Affairs, apud Ogot, Bethwell Allan (2010). In: História geral da África, V: África do século XVI ao XVIII. Brasília: UNESCO, 1976.

MACHADO, Carlos Roma. A região Cuamato-Cuanhama celeiro do planalto: sua questão indígena e relação com a fronteira sul de Angola: repovoação e cultura. In: Boletim da Agência Geral das Colónias, 3(19), 1927, p. 69-84.

. Os serviços de delimitação de fronteiras no sul de Angola em 1927 In: Sociedade de Geografia de Lisboa. Vol. 9-10 (46 série). 1928, p. 335-348.

MACHADO, Ernesto. Relatório da minha missão no sul de Angola em julho - outubro de 1925, p. 46. Arquivo Histórico Diplomático. Limites do Sul de Angola. Fronteira com a colónia alemã do sudoeste africano, 1919/1925. Cota $3^{\circ}$ piso, Armário 9, Maço 22. In: PAULA, Simoni Mendes de (2016) O colonialismo espelhado nas águas do Cunene (1884-1975), Tese de Doutoramento em História, Florianópolis, Universidade Federal de Santa Catarina, Centro de Filosofia e Ciências Humanas. Florianópolis, 2016.

. No sul de Angola. Lisboa: Agência-Geral do Ultramar, 1956.

MAIA, Carlos Roma Machado de Faria. Na Fronteira Sul de Angola. Lisboa: 1941.

MALHOTRA, Naresh K. Pesquisa de marketing: uma orientação. Porto Alegre: Ed. Bookman, 2001.

MINISTÉRIO DO INTERIOR, Serviços de Emigração Estrangeira da República de Angola. Perfil e rotas da imigração ilegal em Angola, 2011.

MONTEIRO, Ramiro Ladeiro. Os Ambós de Angola Antes da Independência. Lisboa: Universidade Técnica de Lisboa, Instituto Superior de Ciências Sociais e Políticas, 1994.

MORAIS, António Trigo de. A água na valorização do ultramar. In: Boletim Geral das Colónias, 27 (313), 1951, p. 11-44.

MWAIKAFANA, Abraão Ndeufekelua. Políticas Públicas e Desafios no Meio Rural Angolano, promoção do Desenvolvimento Sustentável na Aldeia de Ondava (Kwanyama; Kunene). Dissertação de Mestrado em Políticas Públicas e Projectos, Évora: Universidade de Évora. 2018.

NAÇÕES UNIDAS, Conselho Económico Social, Comissão Económica para a África e Comissão da União Africana. In: Alterações climáticas: perspectivas africanas para um acordo pós-2012. 2008.

NETO, José Pereira. O Baixo Cunene: Subsídios para o seu desenvolvimento. In: Estudos de Ciências Políticas e Sociais. Lisboa, Junta de Investigação do Ultramar, 1963.

NEVES, José Luís (1996). Pesquisa qualitativa: características, usos e possibilidades. In: Caderno de Pesquisas em Administração. 1(3), 1-5, 1996.

OLIVEIRA, Elias Chinguli Nunes de. A geopolítica do conflito étnico da região dos Grandes Lagos. Roma: Editorial Nzila, 2005.

OGOT, Bethwell Allan. História geral da África, V: África do século XVI ao XVIII. Brasília: UNESCO, 2010.

PAULA, Simoni Mendes de. O colonialismo espelhado nas águas do Cunene (1884-1975). Tese de Doutoramento em História: Universidade Federal de Santa Catarina, Centro de Filosofia e Ciências Humanas, Florianópolis, 2016. 
PÉLISSER, René. História das campanhas de Angola: resistência e revoltas (1845-1941), vol. 1, Lisboa: Editorial Estampa, 1986.

QUIVY, Raimond e Luc Van Campenhoudt. Manual de investigação em ciências sociais. Lisboa: Gradiva, 1998.

RESOLUÇÃO n ${ }^{\circ}$ 2/07, de 21 de fevereiro, ao abrigo das disposições combinadas da alinea k) do artigo 88 e do $\mathrm{n}^{\circ} 6$ do artigo 92 da Lei Constitucional, aprova o Protocolo de Cooperação no Domínio da Defesa entre o Governo da República de Angola e o Governo da República da Namíbia, de 6 de fevereiro de 2007

RESOLUÇÃO no 21/05 de 17 de agosto, aprova o Acordo Comercial entre o Governo da República de Angola e o Governo da Namíbia, 2005.

RESOLUÇÃO no 3/07, que aprova o Acordo entre o Governo da República de Angola e o Governo da República da Namíbia, sobre a isenção do visto em passaportes diplomáticos, de serviço e ordinários dos cidadãos angolanos e namibianos que se desloquem para o respetivo Estado vizinho, estipulando, 2007.

RESOLUÇÃO no 4/07, que aprova o acordo entre o Governo da República de Angola e o governo da República da Namíbia, sobre a designação e a abertura oficial dos postos de fronteira e pontos de entrada/postos de travessia, tendo em consideração os fusos horários em vigor nos dois países, 2007

REDINHA, José. Etnias e culturas de Angola Luanda. I.I.C.A., 1974

RUQUOY, D. Situação de entrevista e estratégia do entrevistador. In: C. ALBARELLO, J. Hiernaux, C. Maroy, D. Ruquoy, e P. Saint-Georges (eds.). Práticas e métodos de investigação em Ciências Sociais. Lisboa, Gradiva: $2^{\mathrm{a}}$ Ed. 2005, p. 84-116.

ROBERT, Anne-Cécile. Que resta das fronteiras africanas?”, In: Buala, 2013. Disponível em: http://www.buala.org/pt/jogos-sem-fronteiras/que-resta-das-fronteiras-africanas. Consultado em 05.11.2014.

SANTOS, Maria Emília Madeira. Nos caminhos de África: serventia e posse. (Angola no século XIX). Lisboa: Instituto de Investigação Científica Tropical, 1998.

SILVA, Elisete Marques da. Impactos da ocupação colonial nas sociedades rurais do sul de Angola. In: Occasional Paper Series, 8, 2003. Disponível em: http://hdl.handle.net/10071/2731.

UDELSMANN Rodrigues, Cristina. Rapid adaptations to change and displacements in the Lundas (Angola). In: Amanda Hammar. Displacement Economies in Africa: Paradoxes of Crisis and Creativity. London: Zed Books, 2014, p. 107-126

Cunene em movimento: dinâmicas empresariais transfronteiriças. In: Economia Global e Gestão, 12(3), 2007, p. 57-70. Disponível em: http://hdl.handle.net/10071/6258

Esta Fronteira Não Existe (This Border Does Not Exist). 2011 Documentário. Disponível em: http://hdl.handle.net/10071/3029

The Kwanhama partitioned by the border and the Angolan perspective of cross-border identity. In: African Studies, 76(3), 2017, p. 423-443.

ZAU, Filipe. O Grupo Pré-Bantu Vátua. 2010. Disponível em http://jornaldeangola.sapo.ao/cultura/o_grupo_pre-bantu_vatua. Consulta a 18 de janeiro de 2020 
As dinâmicas formais/informais e modus operandi da mobilidade da população fronteiriça do sul de Angola Sónia Cristina Cardoso dos Santos Silva

O Regime Familiar do Grupo Etnolinguistico Khoisan. 2010. Disponível em http://jornaldeangola.sapo.ao/cultura/o_regime_familiar_do_grupo_etnolinguistico_khoisan. Consulta a 18 de janeiro de 2020. 